Prepared in cooperation with the Triangle Area Water Supply Monitoring Project Steering Committee

\title{
Triangle Area Water Supply Monitoring Project, North Carolina-Summary of Monitoring Activities, Quality Assurance, and Data, October 2017-September 2019
}

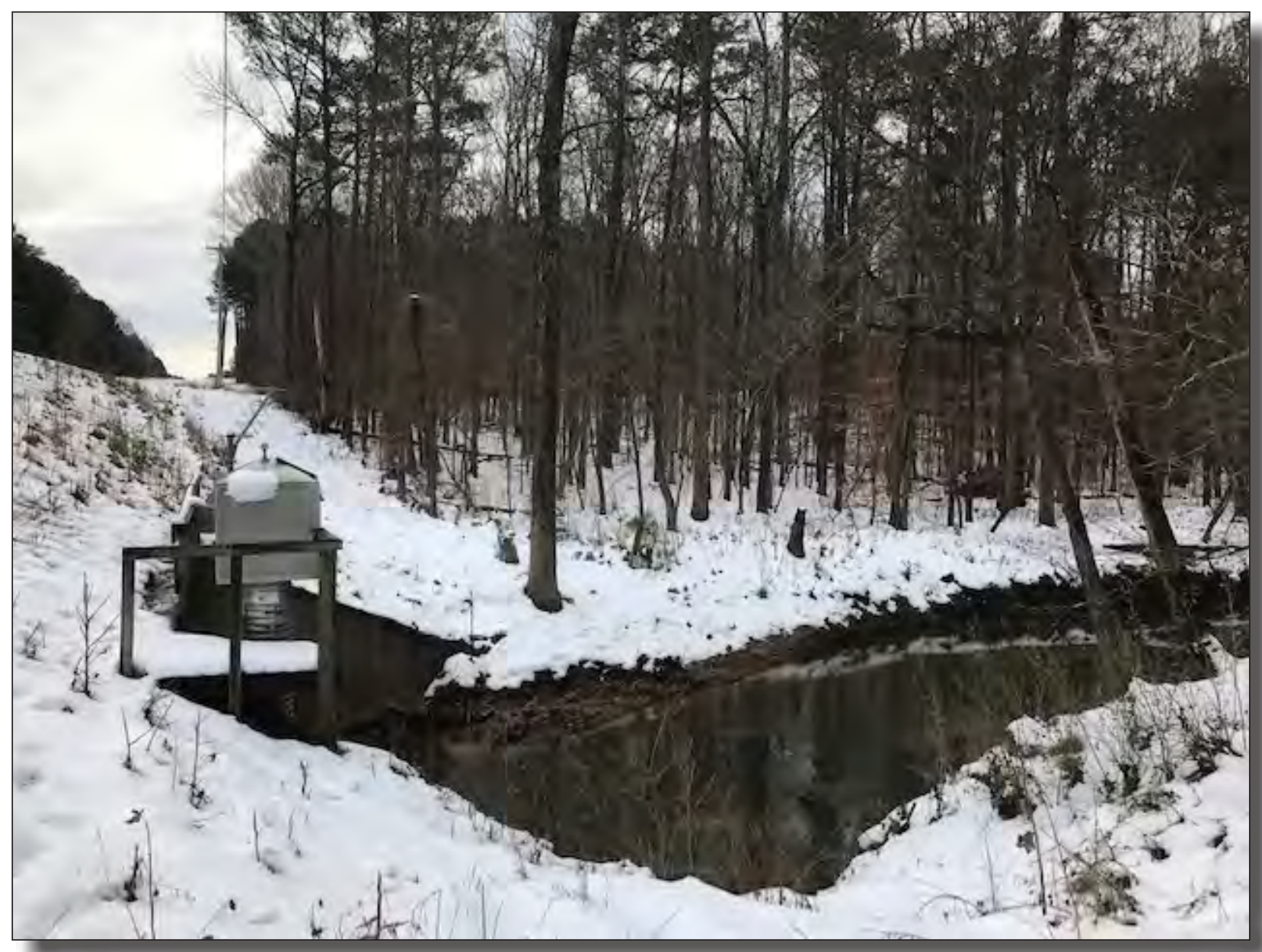

Open-File Report 2021-1020 
Cover. Morgan Creek near White Cross, North Carolina. Photograph taken by Jessica L. Cain, U.S. Geological Survey. 


\section{Triangle Area Water Supply Monitoring Project, North Carolina-Summary of Monitoring Activities, Quality Assurance, and Data, October 2017-September 2019}

By Cassandra A. Pfeifle, Jessica L. Cain, and Ryan B. Rasmussen

Prepared in cooperation with the Triangle Area Water Supply Monitoring Project Steering Committee

Open-File Report 2021-1020 


\section{U.S. Geological Survey, Reston, Virginia: 2021}

For more information on the USGS - the Federal source for science about the Earth, its natural and living resources, natural hazards, and the environment-visit https://www.usgs.gov or call 1-888-ASK-USGS.

For an overview of USGS information products, including maps, imagery, and publications, visit https://store.usgs.gov/.

Any use of trade, firm, or product names is for descriptive purposes only and does not imply endorsement by the U.S. Government.

Although this information product, for the most part, is in the public domain, it also may contain copyrighted materials as noted in the text. Permission to reproduce copyrighted items must be secured from the copyright owner.

Suggested citation:

Pfeifle, C.A., Cain, J.L., and Rasmussen, R.B., 2021, Triangle Area Water Supply Monitoring Project, North CarolinaSummary of monitoring activities, quality assurance, and data, October 2017-September 2019: U.S. Geological Survey Open-File Report 2021-1020, 19 p., https://doi.org/10.3133/ofr20211020.

Associated data for this publication:

Cain, J.L., Pfeifle, C.A., and Rasmussen, R.B., 2020, Associated data for the Triangle Area Water Supply Monitoring Project, North Carolina, October 2017-September 2019: U.S. Geological Survey data release, https://doi.org/10.5066/P9KO6KH2.

ISSN 2331-1258 (online) 


\section{Contents}

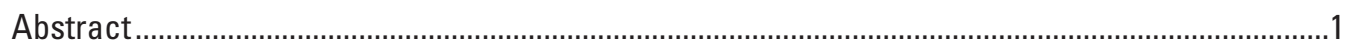

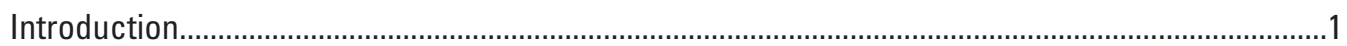

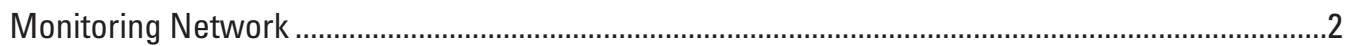

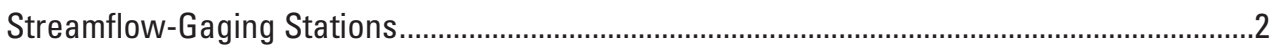

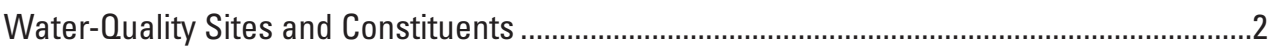

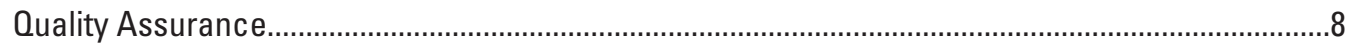

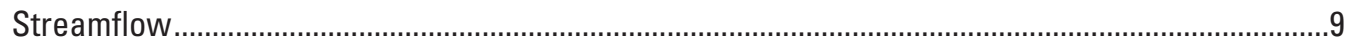

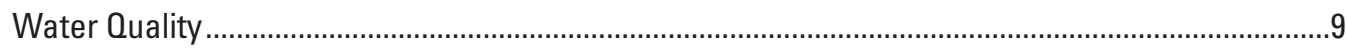

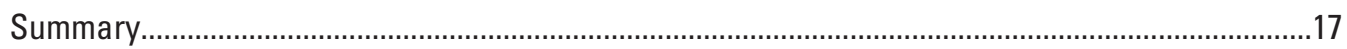

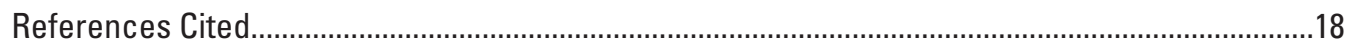

\section{Figures}

1. Map showing locations of Triangle Area Water Supply Monitoring Project data-collection sites in the upper Cape Fear and Neuse River Basins, North Carolina, October 2017-September 2019..

2. Bar graphs showing annual runoff, in inches, measured from 0ctober 2017 through September 2018 and from October 2018 through September 2019, and the long-term mean runoff for the period of record at 10 streamflow-gaging stations in the Triangle area of North Carolina.....

3. Maps showing sites in the Triangle area of North Carolina with one or more measurements of dissolved-oxygen concentration $<5$ milligrams per liter, dissolved-oxygen percent saturation values $>110$ percent, $\mathrm{pH}$ values $>9$ standard units, turbidity values $>25$ nephelometric turbidity ratio units for lakes and reservoirs or $>50$ nephelometric turbidity ratio units for streams, and concentrations of chlorophyll $a>40$ micrograms per liter, October 2017-September 2019

\section{Tables}

1. Water-quality and streamflow monitoring sites for the Triangle Area Water Supply Monitoring Project, October 2017-September 2019.

2. Physical properties measured in the field and chemical constituents analyzed at the U.S. Geological Survey National Water Quality Laboratory and the Analytical Trace Elements Chemistry and Geochemical Modeling of Acid Waters/Redox Chemistry Labs at the U.S. Geological Survey Water Mission Area Laboratories, Boulder, Colorado, for the Triangle Area Water Supply Monitoring Project and the methods used for analysis, October 2017-September 2019.

3. Summary of selected constituent data observed in blank and environmental samples from the Triangle Area Water Supply Monitoring Project, October 2017-September 2019.

4. Summary of water-quality results for sampled sites in the Triangle Area Water Supply Monitoring Project, October 2017-September 2019. 


\section{Conversion Factors}

U.S. customary units to International System of Units

\begin{tabular}{lcl}
\hline \multicolumn{1}{c}{ Multiply } & By & \multicolumn{1}{c}{ To obtain } \\
\hline inch (in.) & Length & \\
mile (mi) & 25.4 & millimeter $(\mathrm{mm})$ \\
& 1.609 & kilometer $(\mathrm{km})$ \\
\hline \multicolumn{3}{c}{ Flow rate } \\
\hline cubic foot per second (ft $3 / \mathrm{s})$ & 0.02832 & cubic meter per second $\left(\mathrm{m}^{3} / \mathrm{s}\right)$ \\
\hline \multicolumn{3}{c}{ Mass } \\
ounce, avoirdupois $(\mathrm{oz})$ & 28.35 & gram $(\mathrm{g})$ \\
pound, avoirdupois $(\mathrm{lb})$ & 0.4536 & kilogram $(\mathrm{kg})$ \\
ton, short $(2,000 \mathrm{lb})$ & 0.9072 & metric ton $(\mathrm{t})$ \\
ton, long $(2,240 \mathrm{lb})$ & 1.016 & metric ton $(\mathrm{t})$ \\
\hline
\end{tabular}

Temperature in degrees Celsius $\left({ }^{\circ} \mathrm{C}\right)$ may be converted to degrees Fahrenheit $\left({ }^{\circ} \mathrm{F}\right)$ as follows: ${ }^{\circ} \mathrm{F}$ $=\left(1.8 \times{ }^{\circ} \mathrm{C}\right)+32$.

\section{Supplemental Information}

Water year is defined as the period from 0ctober 1 to September 30 and is identified by the year in which the period ends. For example, water year 2018 is 0ctober 1, 2017, to September 30, 2018.

Specific conductance is given in microsiemens per centimeter at 25 degrees Celsius $(\mu \mathrm{S} / \mathrm{cm}$ at $\left.25^{\circ} \mathrm{C}\right)$.

Turbidity is given in nephelometric turbidity ratio units (NTRU).

Concentrations of chemical constituents in water are given in either milligrams per liter (mg/L) or micrograms per liter $(\mu \mathrm{g} / \mathrm{L})$. 


\section{Abbreviations}

$\begin{array}{ll}\mathrm{L} & \text { liter } \\ \mathrm{m} & \text { meter } \\ \mathrm{mg} / \mathrm{L} & \text { milligrams per liter } \\ \mathrm{N} & \text { nitrogen } \\ \text { NCDWR } & \text { North Carolina Division of Water Resources } \\ \text { NTRU } & \text { nephelometric turbidity ratio units } \\ \text { NWISWeb } & \text { U.S. Geological Survey National Water Information System } \\ \text { NWOL } & \text { National Water Quality Laboratory } \\ \mathrm{P} & \text { phosphorous } \\ \text { RPD } & \text { relative percent difference } \\ \text { TAWSMP } & \text { Triangle Area Water Supply Monitoring Program } \\ \text { TOC } & \text { total organic carbon } \\ \text { USGS } & \text { U.S. Geological Survey }\end{array}$





\title{
Triangle Area Water Supply Monitoring Project, North Carolina-Summary of Monitoring Activities, Quality Assurance, and Data, October 2017- September 2019
}

\author{
By Cassandra A. Pfeifle, Jessica L. Cain, and Ryan B. Rasmussen
}

\section{Abstract}

Surface-water supplies are important sources of drinking water for residents in the Triangle area of North Carolina, which is located within the upper Cape Fear and Neuse River Basins. Since 1988, the U.S. Geological Survey and a consortium of local governments have tracked water-quality conditions and trends in several of the area's water-supply lakes and streams. This report summarizes data collected through this cooperative effort, known as the Triangle Area Water Supply Monitoring Project, from October 2017 through September 2018 (water year 2018) and from October 2018 through September 2019 (water year 2019). Major findings for this period include the following:

- More than 7,500 individual measurements of water quality were made at 20 sites -7 in the Neuse River Basin and 13 in the Cape Fear River Basin. For the lake sites, only measurements from the photic zone and 1 meter below the water surface are documented in this report.

- Thirty-six water-quality properties or constituents are presented in this report; the State of North Carolina water-quality thresholds are presented for 11 of these.

- All observations met the State of North Carolina waterquality thresholds for water temperature, hardness, chloride, fluoride, sulfate, and nitrate plus nitrite.

- The State of North Carolina water-quality thresholds were exceeded one or more times for dissolved oxygen, dissolved-oxygen percent saturation, $\mathrm{pH}$, turbidity, and chlorophyll $a$.

\section{Introduction}

The Triangle area, located within the upper Cape Fear and Neuse River Basins, is one of the most rapidly developing areas of North Carolina. Population growth continues to increase the demand for water from public suppliers, most of which draw from streams and lakes in the region. Growth also brings the threat of greater loads of pollutants and new contaminant sources that could adversely affect water quality if not properly managed and mitigated.

The Triangle Area Water Supply Monitoring Project (TAWSMP) has tracked water-quality conditions and longterm trends in many of the area's water-supply lakes, rivers, and tributaries for over 30 years. The project has progressed in phases, allowing for flexibility in the monitoring network and partners, and timely responses to emerging water-quality concerns. The most recent publication in this series, Pfeifle and others (2019), reported results for water years 2016 and 2017. The objectives of the project for water years 2018 and 2019 were as follows:

- Extend the existing long-term water-quality dataset for nutrients, sediment, major ions, and selected metals to track spatial variations in water quality, loads to reservoirs, and long-term water-quality trends.

- Continue monitoring at tributary sites during high-flow events to increase the understanding of constituent concentrations and loads during extreme hydrologic conditions.

- Maintain a network of 10 continuous streamflowgaging stations in the study area.

- Investigate the occurrence and distribution of additional water-quality parameters, including bromide, 1,4-dioxane, and chromium (hexavalent, filtered, and total).

Under an agreement with several local governments in North Carolina, the U.S. Geological Survey (USGS) monitors hydrologic conditions and collects water-quality samples. One site in the Triangle area consists only of a streamflow gage. Continuous streamflow is recorded at most stream sites and funded through the TAWSMP and other USGS programs. The USGS is responsible for data quality assurance, analysis, and interpretation, providing the data to the public, 
and maintaining the database in perpetuity. Funding for the project is provided by local government partners (see sidebar) and by the USGS through Cooperative Matching Funds (https://www.usgs.gov/mission-areas/water-resources/science/ usgs-cooperative-matching-funds?qt-science_center_objects= 0\#qt-science_center_objects). The Triangle J Council of Governments provides organizational support services for the TAWSMP.

\section{Triangle Area Water Supply Monitoring Project Partners, 2018-19}

Chatham County

Orange County

Town of Apex

Town of Cary

City of Durham

Town of Hillsborough

Town of Morrisville

Orange Water and Sewer Authority

Triangle J Council of Governments

U.S. Geological Survey

For more information on the project, go to

https://tawsmp.org/.

This report summarizes monitoring activities and data collected by the USGS for the TAWSMP from October 2017 through September 2019, which is referred to as water years 2018 (October 2017 to September 2018) and 2019 (October 2018 to September 2019). Hydrologic conditions in the Triangle area are also described in this report. Ranges of concentrations for water-quality in situ measurements (dissolved oxygen, $\mathrm{pH}$, specific conductance, water temperature, and turbidity), acid-neutralizing capacity, major ions (calcium, magnesium, potassium, sodium, bromide, chloride, fluoride, silica, and sulfate), nutrients (ammonia plus organic nitrogen, ammonia, nitrate plus nitrite as nitrogen, orthophosphate, and phosphorus), 1,4-dioxane, total organic carbon (TOC), chlorophyll $a$, pheophytin $a$, chromium (hexavalent, filtered, and unfiltered), and suspended sediment are presented for each site sampled during this period. The supporting data for this report are available in Cain and others (2020).

\section{Monitoring Network}

Since the project began in 1988, several adjustments were made to the sampling locations, sampling frequency, and measured constituents. During 2018-19, the TAWSMP monitoring network comprised 22 sites, including streamflowgaging stations and stream and lake water-quality sampling sites (fig. 1). Water-quality samples were collected at 20 sites during this period. Project sampling, analytical methods, and quality-assurance practices are described in Oblinger (2004).
In August 2017, sample collection at Little River Reservoir (site 5) and Lake Michie (site 7) resumed under a new 5-year agreement with the Triangle J Council of Governments. Changes in water-quality analyses for this reporting period included the addition of bromide, 1,4-dioxane, and chromium (hexavalent, filtered, and total) and pheophytin $a$. The data collected as part of this project are available to project partners and the public through the USGS National Water Information System (NWISWeb) database (U.S. Geological Survey, 2020b) and Cain and others (2020).

\section{Streamflow-Gaging Stations}

Streamflow records are useful for managing water supplies and essential for determining instream loads of sediment, nutrients, and other constituents, and for interpreting water-quality trends. The USGS operates 10 continuous-record streamflow-gaging stations funded through the TAWSMP (table 1). These gages record water levels at 15-minute intervals and display this information along with calculated discharge through the USGS NWISWeb database in near-real time (U.S. Geological Survey, 2020b).

\section{Water-Quality Sites and Constituents}

Water-quality data are used to track current conditions and analyze long-term water-quality trends and pollutant loads in the Triangle area. The USGS monitored water quality at 20 sites in the TAWSMP study area during water years 2018 and 2019. More than 7,500 individual measurements of the physical properties and water chemistry of these locations were made during this time. The parameters measured and the analytical methods used are presented in table 2. Measurements were made at 7 sites in the Neuse River Basin and 13 sites in the Cape Fear River Basin.

Nine sites at six public water-supply lakes were sampled, including West Fork Eno River Reservoir (site 1), Little River Reservoir (site 5), and Lake Michie (site 7) in the Neuse River Basin, and Cane Creek Reservoir (site 9), University Lake (site 15), and Jordan Lake (sites 11, 18, 20, 21) in the Cape Fear River Basin (table 1; fig. 1). Jordan Lake is a large, multipurpose reservoir managed by the U.S. Army Corps of Engineers. All four sites in Jordan Lake were sampled bimonthly during water years 2018 and 2019. The five smaller reservoirs are used primarily for water supply; three also provide recreational access. One site in each of the smaller lakes was sampled six times per year.

Lake samples were collected at multiple depths, but only the samples collected within the photic zone and at 1 meter (m) below the water surface are summarized in this report. Vertical profiles of field parameters (dissolved oxygen, $\mathrm{pH}$, specific conductance, and water temperature) were measured at 1-m depth intervals at the sampling location, along with water transparency, which was measured by Secchi disk. 
Water samples were collected for the analysis of turbidity, acid-neutralizing capacity, major ions (calcium, magnesium, potassium, sodium, bromide, chloride, fluoride, silica, and sulfate), nutrients (ammonia plus organic nitrogen, ammonia, nitrate plus nitrite, orthophosphate, and phosphorus), 1,4-dioxane, TOC, chlorophyll $a$, pheophytin $a$, chromium (hexavalent, filtered, and unfiltered), and unfiltered iron and manganese during each sampling trip. In this report, turbidity values are reported in nephelometric turbidity ratio units (NTRU). Ammonia plus organic nitrogen, ammonia, and nitrate plus nitrite are reported in milligrams per liter as nitrogen $(\mathrm{mg} / \mathrm{L}$ as $\mathrm{N})$, and orthophosphate and phosphorus are reported in milligrams per liter as phosphorus $(\mathrm{mg} / \mathrm{L}$ as $\mathrm{P}$ ).

The USGS sampled four stream sites on a bimonthly basis to measure water-quality field properties, major ions, nutrients, 1,4-dioxane, TOC, chromium (hexavalent, filtered, and unfiltered), and suspended sediment. These sites include Eno River at Hillsborough (site 2), Cane Creek near Orange Grove (site 8), Morgan Creek near White Cross (site 14), and White Oak Creek (site 19) (fig. 1; table 1). Samples were collected at multiple locations along a transect and were composited. Sampling was not conducted during no-flow conditions, which occasionally occurred at the smaller streams.

During water years 2018 and 2019, routine sampling at the nine lake sites and the four bimonthly stream sites was conducted according to the planned schedule. The analysis for nutrients (ammonia plus organic nitrogen, ammonia, nitrate plus nitrite, orthophosphate, and phosphorus), 1,4-dioxane, and TOC in several samples was potentially affected by a partial Federal Government shutdown beginning in December 2018. The TOC samples were not filtered or preserved with acid; therefore, the USGS National Water Quality Laboratory (NWQL) did not process the December 2018 TOC samples due to the potential for microbial degradation after the established holding time was exceeded. The nutrient and 1,4-dioxane results potentially affected by a partial Federal Government shutdown are flagged in Cain and others (2020).

In addition to bimonthly sampling at the four stream sites, the study design included eight additional stream sites in the TAWSMP network to be sampled only during storm-runoff events when water levels rapidly increased because of rainfall events. During 2018-19, seven additional stream sites were sampled by the USGS during selected storm-runoff events, including Eno River at Durham (site 3), Little River near Orange Factory (site 4), Flat River at Bahama (site 6), Haw River near Bynum (site 10), New Hope Creek near Blands (site 12), Northeast Creek near Genlee (site 13), and Haw River below B. Everett Jordan Lake dam near Moncure (site 22). These higher flow samples supplement fixed-interval data collected by the North Carolina Division of Water Resources (NCDWR) as part of the Ambient Monitoring System (https://deq.nc.gov/about/divisions/water-resources/waterresources-data/water-sciences-home-page/ecosystems-branch/ ambient-monitoring-system).

The four supplemental storm-runoff samples from Little River near Orange Factory (site 4) were collected using a portable automatic sampler according to USGS protocols (U.S. Geological Survey, variously dated). Once the preprogrammed water-level condition for the stream was met, water was collected through an intake line and directly composited into an 8-liter (L) plastic churn splitter. The samples were processed within 24 hours of collection using the same processing techniques as the routine samples (U.S. Geological Survey, variously dated). The 1,4-dioxane and TOC samples were obtained by a grab sample when the 8 -L plastic churn splitter was retrieved from the portable automatic sampler for processing. Dissolved oxygen, $\mathrm{pH}$, and water temperature were not measured for runoff samples because of changes during storage in the automated sampler before processing. Occasionally, there was insufficient water to conduct all planned analyses. Water-quality results for the seven streams sampled only during high stream-runoff events likely do not represent typical water-quality conditions for these sites.

Acid-neutralizing capacity was determined within a few hours of sampling in the field or the office laboratory using USGS standard methods (U.S. Geological Survey, variously dated). The nutrient and major-ions analyses were conducted at the USGS NWQL in Denver, Colorado. The 1,4-dioxane analyses were conducted at the Analytical Trace Elements Chemistry and Geochemical Modeling of Acid Waters/Redox Chemistry Labs at the USGS Water Mission Area Laboratories in Boulder, Colorado. The water samples were analyzed for suspended sediment concentrations at the USGS Eastern Region Sediment Laboratory in Louisville, Kentucky. 


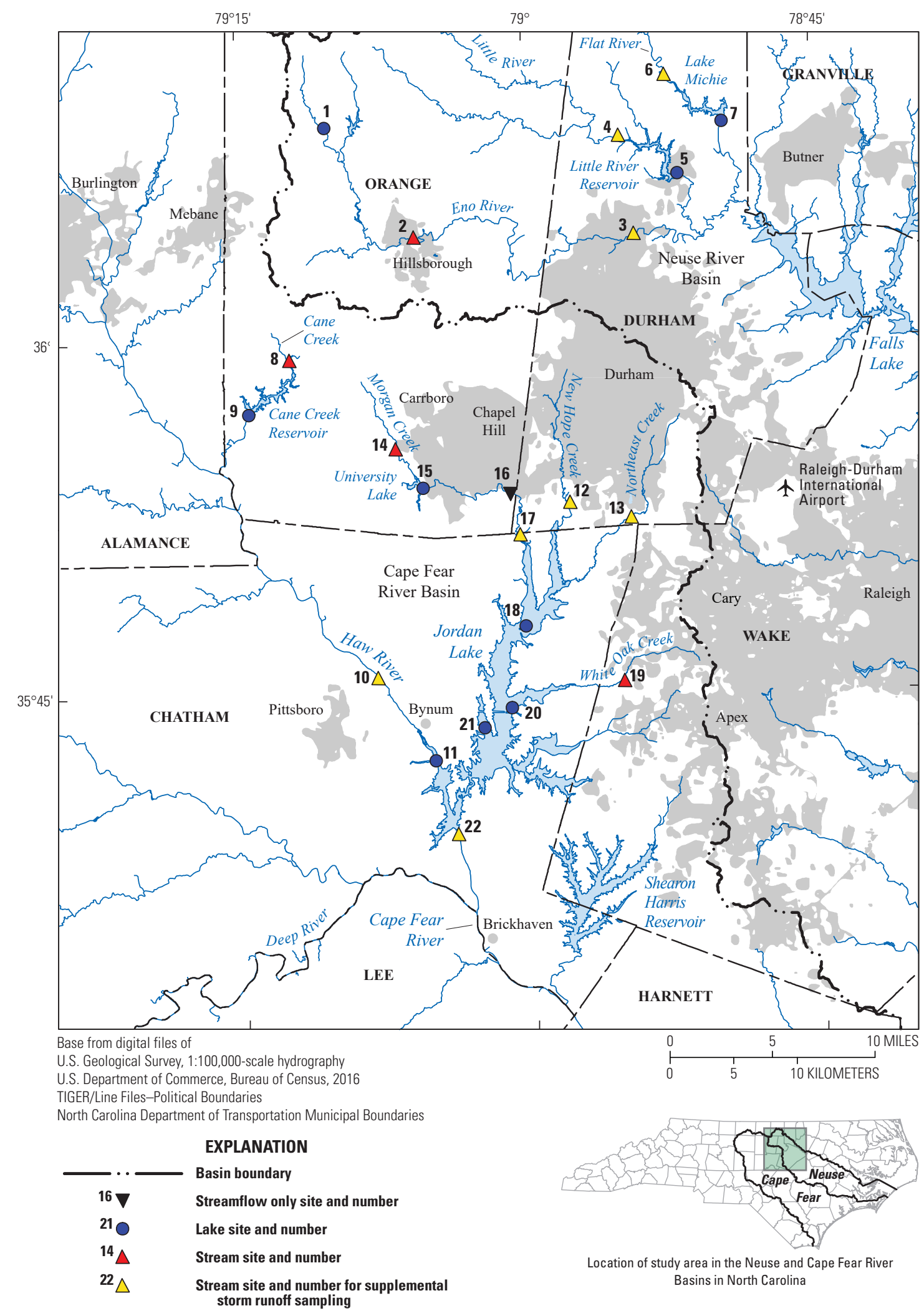

Figure 1. Map showing locations of Triangle Area Water Supply Monitoring Project data-collection sites in the upper Cape Fear and Neuse River Basins, North Carolina, October 2017-September 2019. 
Table 1. Water-quality and streamflow monitoring sites for the Triangle Area Water Supply Monitoring Project, October 2017September 2019.

[USGS, U.S. Geological Survey; Lake, lake sites sampled bimonthly; Stream (routine), stream sites sampled bimonthly and during runoff; Stream (runoff), stream sites sampled only during runoff events; n/a, not applicable; --, data were not collected (refer to footnote); SR, secondary road; USACE, U.S. Army Corps of Engineers]

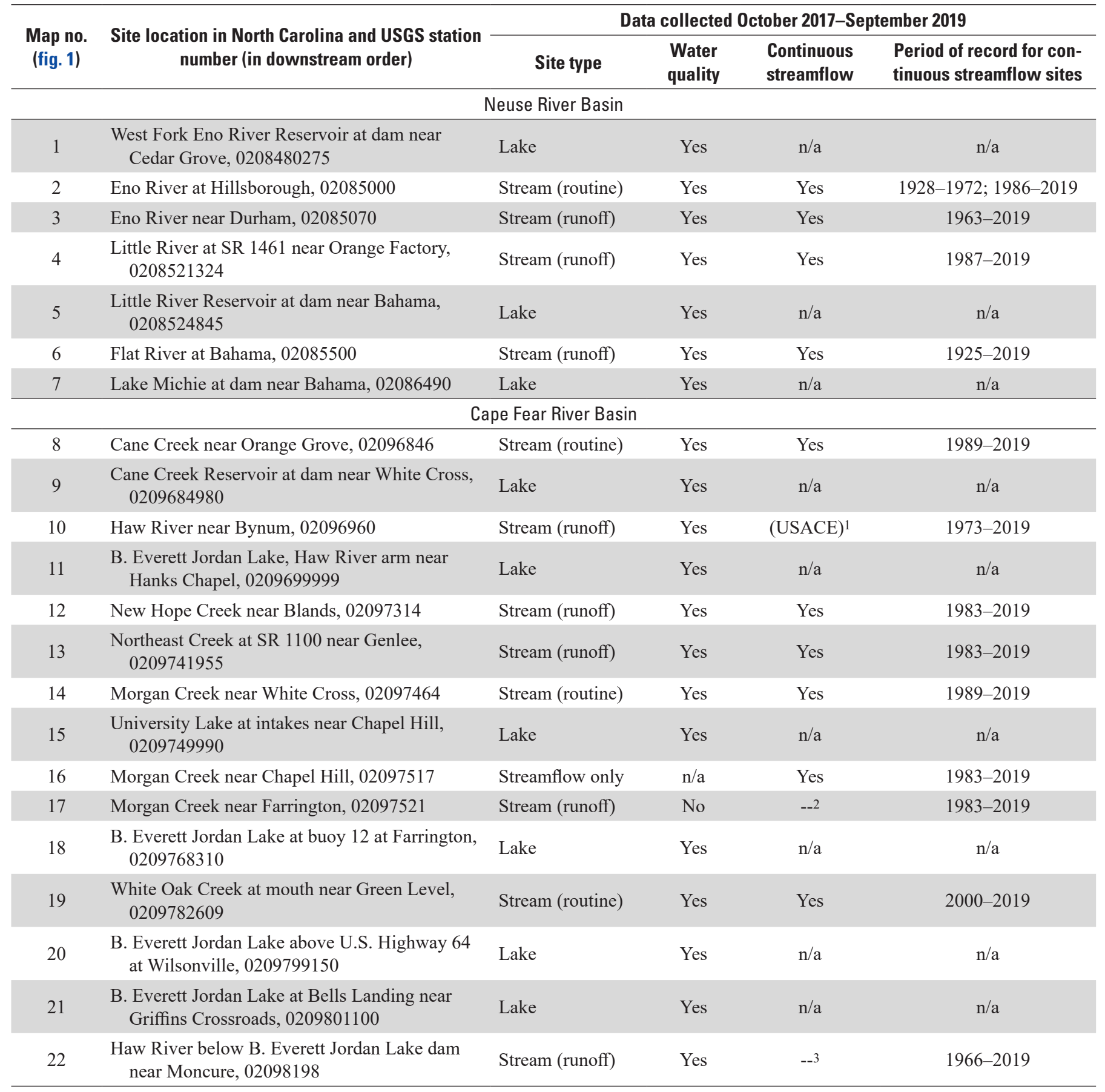

${ }^{1}$ Gage funded through separate agreement with the USACE.

${ }^{2}$ Streamflow from nearby gage, Morgan Creek near Chapel Hill, North Carolina (USGS station 02097517).

${ }^{3}$ Streamflow computed from USACE releases from the Jordan Lake dam. 
Table 2. Physical properties measured in the field and chemical constituents analyzed at the U.S. Geological Survey (USGS) National Water Quality Laboratory (NWQL) and the Analytical Trace Elements Chemistry and Geochemical Modeling of Acid Waters/Redox Chemistry Labs at the USGS Water Mission Area Laboratories, Boulder, Colorado, for the Triangle Area Water Supply Monitoring Project and the methods used for analysis, October 2017-September 2019.

[NWIS, National Water Information System; ${ }^{\circ} \mathrm{C}$, degree Celsius; USGS, U.S. Geological Survey; m, meter; $\mu \mathrm{S} / \mathrm{cm}$ at $25^{\circ} \mathrm{C}$, microsiemens per centimeter at 25 degrees Celsius; $\mathrm{mg} / \mathrm{L}$, milligram per liter; NTRU, nephelometric turbidity ratio units; $\mathrm{pH}$, negative $\log$ (base 10 ) of the hydrogen ion activity; $\mathrm{CaCO}_{3}$, calcium carbonate; N, nitrogen; P, phosphorus; USEPA, U.S. Environmental Protection Agency; $\mathrm{SiO}_{2}$, silicon dioxide; $\mu \mathrm{g} / \mathrm{L}$, microgram per liter; DA, (automated) discrete analyzer; ASF, automated segmented flow; Field, analysis performed in the field; USGSWMAL, USGS Water Mission Area Laboratories; USGSSDKY, USGS-Kentucky District Sediment Lab]

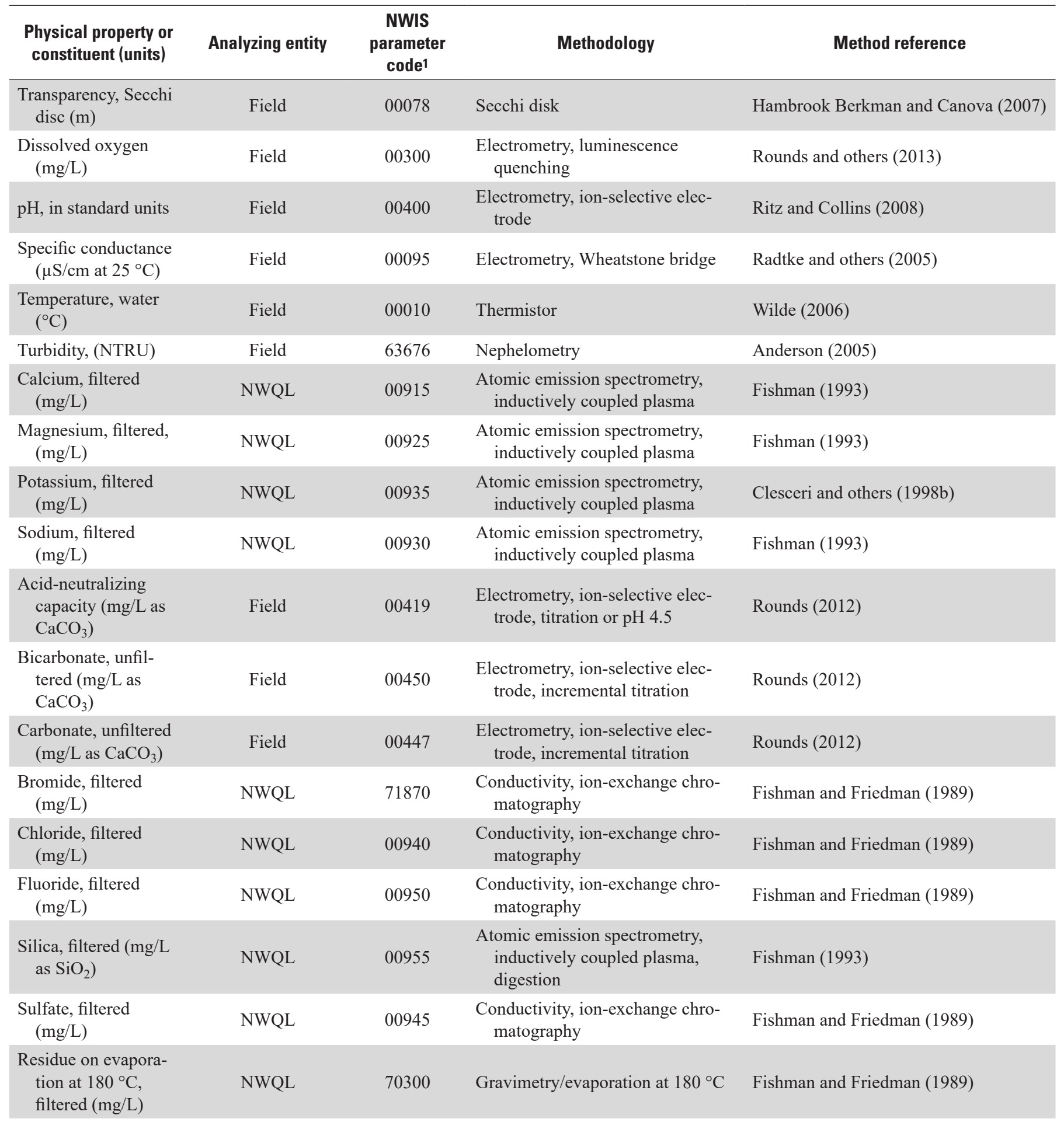


Table 2. Physical properties measured in the field and chemical constituents analyzed at the U.S. Geological Survey (USGS) National Water Quality Laboratory (NWOL) and the Analytical Trace Elements Chemistry and Geochemical Modeling of Acid Waters/Redox Chemistry Labs at the USGS Water Mission Area Laboratories, Boulder, Colorado, for the Triangle Area Water Supply Monitoring Project and the methods used for analysis, October 2017-September 2019.-Continued

[NWIS, National Water Information System; ${ }^{\circ} \mathrm{C}$, degree Celsius; USGS, U.S. Geological Survey; m, meter; $\mu \mathrm{S} / \mathrm{cm}$ at $25^{\circ} \mathrm{C}$, microsiemens per centimeter at 25 degrees Celsius; $\mathrm{mg} / \mathrm{L}$, milligram per liter; NTRU, nephelometric turbidity ratio units; $\mathrm{pH}$, negative $\log$ (base 10 ) of the hydrogen ion activity; $\mathrm{CaCO}_{3}$, calcium carbonate; N, nitrogen; P, phosphorus; USEPA, U.S. Environmental Protection Agency; $\mathrm{SiO}_{2}$, silicon dioxide; $\mu \mathrm{g} / \mathrm{L}$, microgram per liter; DA, (automated) discrete analyzer; ASF, automated segmented flow; Field, analysis performed in the field; USGSWMAL, USGS Water Mission Area Laboratories; USGSSDKY, USGS-Kentucky District Sediment Lab]

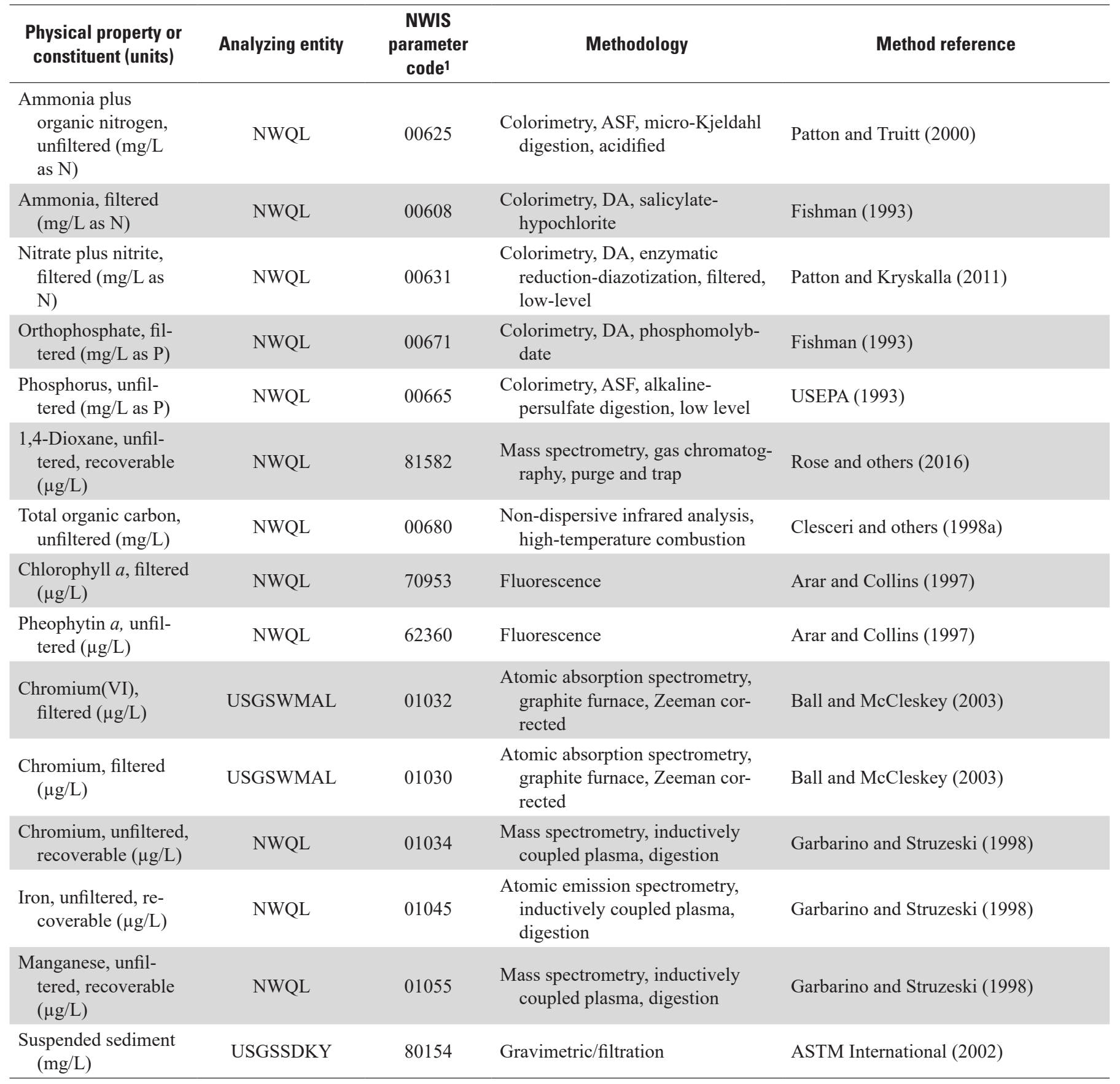

${ }^{1}$ Each parameter code is defined in National Water Information (NWIS)Web: https://nwis.waterdata.usgs.gov/usa/nwis/pmcodes. 
The chlorophyll $a$ and pheophytin $a$ analyses were conducted by the USGS NWQL. The NWQL participated in the chlorophyll $a$ interlaboratory performance comparisons (round robins) sponsored by the NCDWR during 2018 and 2019 and demonstrated acceptable performance.

\section{Quality Assurance}

Quality-control samples, consisting of equipment blanks, sampling-vehicle (ambient) blanks, field blanks, and replicate samples, were collected, analyzed, and reviewed throughout the study to ensure that project data-quality objectives were met (Oblinger, 2004). The source solution for sampling-vehicle and field blanks was inorganic-blank or organic-blank water (depending on the constituents to be analyzed) and was obtained from the USGS National Field Supply Service. Approximately 15 percent of the total samples collected during the study period consisted of quality-control samples. Quality-control samples and collection procedures are described in chapter A4 of the USGS National Field Manual (U.S. Geological Survey, variously dated). Quality-assurance data for this report are available at Cain and others (2020).

Six equipment blanks, 8 sampling-vehicle blanks, and 13 field blanks were collected and analyzed from October 2017 through September 2019 for major ions, nutrients, trace metals, bromide, 1,4-dioxane, chromium (hexavalent, filtered, total), chlorophyll $a$, pheophytin $a$, TOC, and suspended sediment. In all, 24 constituents were analyzed, and 453 blank results were generated. Approximately 96 percent of the results were below censoring levels, indicating minimal contamination during this period. Overall, there were 19 constituent detections, which represents approximately 4 percent of the results. Of these blank results, 11 were low-level detections of ammonia; the remaining 8 detections were distributed among 5 other constituents, including chloride, nitrate plus nitrite, phosphorus, pheophytin $a$, and suspended sediment.

As noted in the previous publication in this series for water years 2010 and 2011 (Pfeifle and others, 2016), a constituent detection rate of 10 percent or less in the combined equipment, vehicle, and field blanks was deemed acceptable. If a constituent was detected in $>10$ percent of the blanks, the results for that constituent were assessed for the potential to positively bias the environmental results. Four constituents exceeded the 10 percent blank-detection threshold, including chloride (19 percent), ammonia (42 percent), pheophytin $a$ ( 25 percent), and suspended sediment ( 20 percent). For these constituents, blank detections were further evaluated based on the proximity to censoring levels and the relevance to corresponding environmental concentrations. Environmental concentrations less than five times the median of the quantified blank detections were considered to have the potential for contamination (table 3). Concentrations of chloride and pheophytin $a$ in all environmental samples were higher than the threshold and likely were not biased by contamination; therefore, these constituents were not listed in table 3.

Ammonia was detected in one equipment blank, four vehicle blanks, and six field blanks, with a median detection concentration of $0.01 \mathrm{mg} / \mathrm{L}$. Therefore, environmental ammonia concentrations $\geq 0.01$ and $<0.05 \mathrm{mg} / \mathrm{L}$ were considered potentially biased. During water years 2018-19, approximately 34 percent of the environmental ammonia concentrations were within this range and should be interpreted cautiously (table 3 ).

Suspended sediment was detected in one field blank, and this detection was near the censoring level of $0.5 \mathrm{mg} / \mathrm{L}$. The detection was $1.0 \mathrm{mg} / \mathrm{L}$; therefore, a potential-contamination threshold of $5.0 \mathrm{mg} / \mathrm{L}$ was computed. Concentrations in environmental samples ranged from $<0.5$ to $1,160 \mathrm{mg} / \mathrm{L}$. Approximately 14 percent had concentrations $<5.0 \mathrm{mg} / \mathrm{L}$ threshold and thus may be biased (table 3).

Low-level ammonia atmospheric concentrations are prevalent in natural and laboratory environments. Despite the known atmospheric contamination issues related to ammonia (Fishman, 1993), the number of blank detections was deemed acceptable for this project. Most of the detections for other constituents occurred infrequently, and concentrations were at or near constituent censoring levels, indicating negligible systematic positive bias.

The variability associated with sampling and analysis was assessed with 24 sets of field replicates analyzed for multiple constituents (Cain and others, 2020). Among the 24 sets of field replicates analyzed for one or more of 27 constituents, there were a total of 211 replicate-result pairs. Paired concentrations with a relative percent difference (RPD; absolute difference multiplied by 100 and divided by the average) $<25$ percent were considered to demonstrate acceptable reproducibility. Of the 211 replicate set pairs, approximately 97 percent had RPDs $<25$ percent.

The seven occurrences of RPDs $>25$ percent involved small absolute concentration differences within the pairs. Bromide, ammonia plus organic nitrogen, chromium, and suspended sediment had replicate sets in this category. Large RPDs coupled with small absolute differences near the constituent censoring level are not uncommon and do not usually indicate a precision problem. For example, one chromium replicate set had an RPD of 40 percent; however, the absolute concentration difference was $0.1 \mu \mathrm{g} / \mathrm{L}$, and the censoring level was $0.2 \mu \mathrm{g} / \mathrm{L}$.

When the absolute concentration difference is greater than or equal to three times the censoring level and is associated with a large RPD, high variability is indicated (Pfeifle and others, 2016). One ammonia plus organic nitrogen replicate set had an RPD of 32 percent and an absolute difference of $0.26 \mathrm{mg} / \mathrm{L}$, which exceeds three times the censoring level $(0.07 \mathrm{mg} / \mathrm{L})$. Additionally, two replicate pairs for suspended sediment had RPDs of 35 percent and 100 percent, with absolute differences of $3 \mathrm{mg} / \mathrm{L}$ and $2 \mathrm{mg} / \mathrm{L}$, which were six times and four times the censoring level of $0.5 \mathrm{mg} / \mathrm{L}$, respectively. Constituents such as suspended sediment are inherently difficult to replicate because 
Table 3. Summary of selected constituent data observed in blank and environmental samples from the Triangle Area Water Supply Monitoring Project, October 2017-September 2019.

$[\mathrm{N}$, nitrogen; $\mathrm{P}$, phosphorus; $<$, less than $]$

\begin{tabular}{|c|c|c|c|c|c|c|c|c|}
\hline \multirow[b]{3}{*}{ Constituent } & \multirow[b]{3}{*}{ Units } & \multirow[b]{3}{*}{$\begin{array}{l}\text { Censoring } \\
\text { level }\end{array}$} & \multicolumn{4}{|c|}{ Blanks } & \multirow{2}{*}{\multicolumn{2}{|c|}{ Environmental samples }} \\
\hline & & & \multicolumn{4}{|c|}{ Blanks with detections } & & \\
\hline & & & Number & Percent & $\begin{array}{l}\text { Range of } \\
\text { quantified } \\
\text { detections }\end{array}$ & $\begin{array}{l}5 \text { times the } \\
\text { median } \\
\text { quantified } \\
\text { detection }\end{array}$ & $\begin{array}{l}\text { Range of } \\
\text { values }\end{array}$ & $\begin{array}{c}\text { Percent }<5 \text { times the } \\
\text { median concentration } \\
\text { detected in a blank }\end{array}$ \\
\hline $\begin{array}{l}\text { Ammonia, } \\
\text { filtered }\end{array}$ & $\begin{array}{c}\text { milligrams per } \\
\text { liter as } \mathrm{N}\end{array}$ & 0.01 & 11 of 26 & 42 & 0.01 & 0.05 & $<0.01-1.39$ & 34 \\
\hline $\begin{array}{l}\text { Suspended } \\
\text { sediment }\end{array}$ & $\begin{array}{l}\text { milligrams per } \\
\text { liter }\end{array}$ & 0.5 & 1 of 5 & 20 & 1 & 5 & $<0.5-1160$ & 14 \\
\hline
\end{tabular}

suspended particles are often not homogenously distributed in the water column or over a cross section. Ammonia plus organic nitrogen and suspended sediment usually showed acceptable reproducibility, but replicate sets continue to be closely monitored. Overall, results for replicate pairs indicated acceptable reproducibility for all water-quality constituents measured during water years 2018 and 2019.

\section{Streamflow}

Streamflow data collected at all 10 gaging stations (fig. 1; table 1) for the TAWSMP were reviewed, quality-assured, and published as print-ready water-year summaries for water years 2018 and 2019 (U.S. Geological Survey, 2020a). Detailed data and summary statistics are also available online through the USGS NWISWeb database (U.S. Geological Survey, 2020b). Streamflow is summarized below in terms of annual runoff compared with the long-term mean for each station's period of record. Annual runoff was computed by dividing the total average discharge (in cubic feet per second) for the water year by the drainage area of the stream. The long-term mean was calculated using the annual runoff for the entire period of record, the length of which varies among the sites (table 1). At some sites, including New Hope Creek near Blands (site 12), Northeast Creek near Genlee (site 13), and Morgan Creek near Chapel Hill (site 16), a significant percentage of the instream flow consists of treated effluent from municipal water reclamation facilities (fig. 1; table 1). These continuous inputs contribute to higher instream baseflows and mitigate the effects of drought on annual runoff.

Streamflow in water year 2018 was above the long-term mean at four sites, including Northeast Creek near Genlee (site 13), Morgan Creek near White Cross (site 14), Morgan Creek near Chapel Hill (site 16), and White Oak Creek (site 19), with annual runoff values for all 10 sites ranging from 6.1 to 23.6 inches (fig. $2 A$ ). White Oak Creek had periods of zero flow in water year 2018. In water year 2019, streamflow was above the long-term mean at all the sites. Annual runoff in water year 2019 ranged from 24.7 to 31.1 inches among the 10 gaging stations (fig. 2B). Morgan Creek near White Cross and White Oak Creek had periods of zero flow during water year 2019.

\section{Water Quality}

Water-quality data were reviewed, and quality-assurance analyses were conducted. Ranges of concentrations observed at each site for 36 properties or constituents are presented in table 4. Dissolved-oxygen percent saturation, hardness, and total nitrogen were computed using USGS National Water Information System (NWIS) algorithms. Although the lake sites were sampled at multiple depths, only results from the photic zone and $1 \mathrm{~m}$ below the water surface for the lake sites are included in this report. All water-quality data summarized in this report are presented in Cain and others (2020). Additional data for lake samples collected in nearbottom waters can be obtained from the USGS NWISWeb database (https://doi.org/10.5066/F7P55KJN) or by request from the USGS South Atlantic Water Science Center (https://www.usgs.gov/centers/sa-water).

The NCDWR adopted instream water-quality thresholds for 11 constituents monitored by the TAWSMP (table 4). All project sampling sites are classified for water-supply use; therefore, applicable standards are the most stringent values established to protect freshwater aquatic life, water supply, or human health (North Carolina Department of Environmental Quality, 2020). Individual observations that do not meet water-quality thresholds do not necessarily constitute violations of the standards nor indicate that the body of water is impaired; however, the thresholds are useful for comparative purposes. Maximum contaminant levels and National Secondary Drinking Water Regulations are established by the U.S. Environmental Protection Agency for five monitored 
constituents (U.S. Environmental Protection Agency, 2020). These criteria apply only to treated potable water - not to raw water supplies - and are provided solely for reference.

Concentration ranges shown in table 4 in bold font indicate that at least one sample for the constituent at that location exceeded a North Carolina water-quality threshold. Some nutrient and 1,4-dioxane values were potentially affected by holding-time violations due to the NWQL being closed during a partial Federal Government shutdown (see footnotes 7 and 8 in table 4). Out of the 159 TOC routine samples collected during the scope of this report, 17 samples were not analyzed due to the partial Federal Government shutdown. Seven TOC samples underwent holding-time violations for other reasons, such as equipment malfunctions. Exceedances of water-quality thresholds occurred at 19 of the 20 sites for at least 1 constituent. The only site with no exceedances of water-quality thresholds was Haw River below B. Everett Jordan Lake dam near Moncure (site 22). Values exceeded thresholds for 5 water-quality constituents: dissolved oxygen (14 samples, 6 lake sites, 1 stream site), dissolved-oxygen percent saturation (21 samples, 9 lake sites, 2 stream sites), $\mathrm{pH}$ (1 sample, 1 lake site), turbidity (22 samples, 5 lake sites, 8 stream sites), and chlorophyll $a$ (22 samples, 9 lake sites) and are included in table 4 and figure 3. No exceedances of State water-quality thresholds were observed for six constituents: water temperature, hardness, chloride, fluoride, sulfate, and nitrate plus nitrite (table 4).
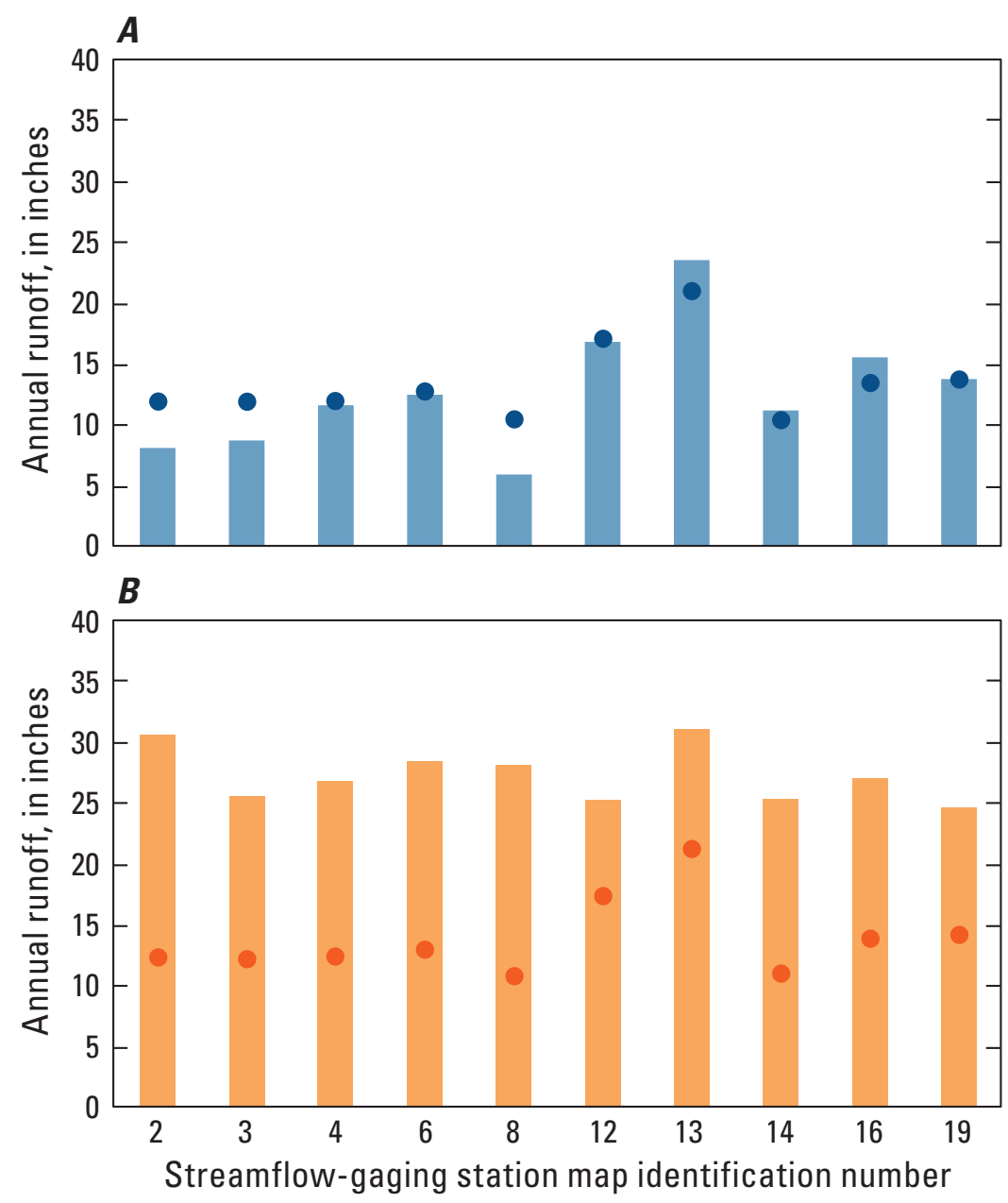

\section{EXPLANATION}

Water year 2018 annual runoff

- Long-term mean of record

\section{EXPLANATION}

Water year 2019 annual runoff

- Long-term mean of record

Figure 2. Bar graphs showing annual runoff, in inches, measured from $(A)$ October 2017 through September 2018 (water year 2018) and from (B) October 2018 through September 2019 (water year 2019), and the long-term mean runoff for the period of record at 10 streamflow-gaging stations in the Triangle area of North Carolina. Map identification numbers and the periods of record, which vary among stations, are given in table 1. 
Table 4. Summary of water-quality results for sampled sites in the Triangle Area Water Supply Monitoring Project, October 2017-September 2019.

[Number under site name refers to the map number shown in figure 1 and table 1. NCDWR, North Carolina Division of Water Resources; MCL, maximum contaminant level; SDWR, secondary drinking water regulation; n, number of observations; range, minimum and maximum values; --, not available or constituent not sampled; $\mathrm{m}$, meter; $\mathrm{mg} / \mathrm{L}$, milligram per liter; $>$, greater than; $<$, less than; $\mu \mathrm{S} / \mathrm{cm}$, microsiemens per centimeter; C, Celsius; NTRU, nephelometric turbidity ratio units; $\mathrm{CaCO}_{3}$, calcium carbonate; N, nitrogen; P, phosphorus; $\mu \mathrm{g} / \mathrm{L}$, microgram per liter; WS, water supply; exceedances of the NCDWR waterquality criterion are shown in bold. See footnotes at end of table]

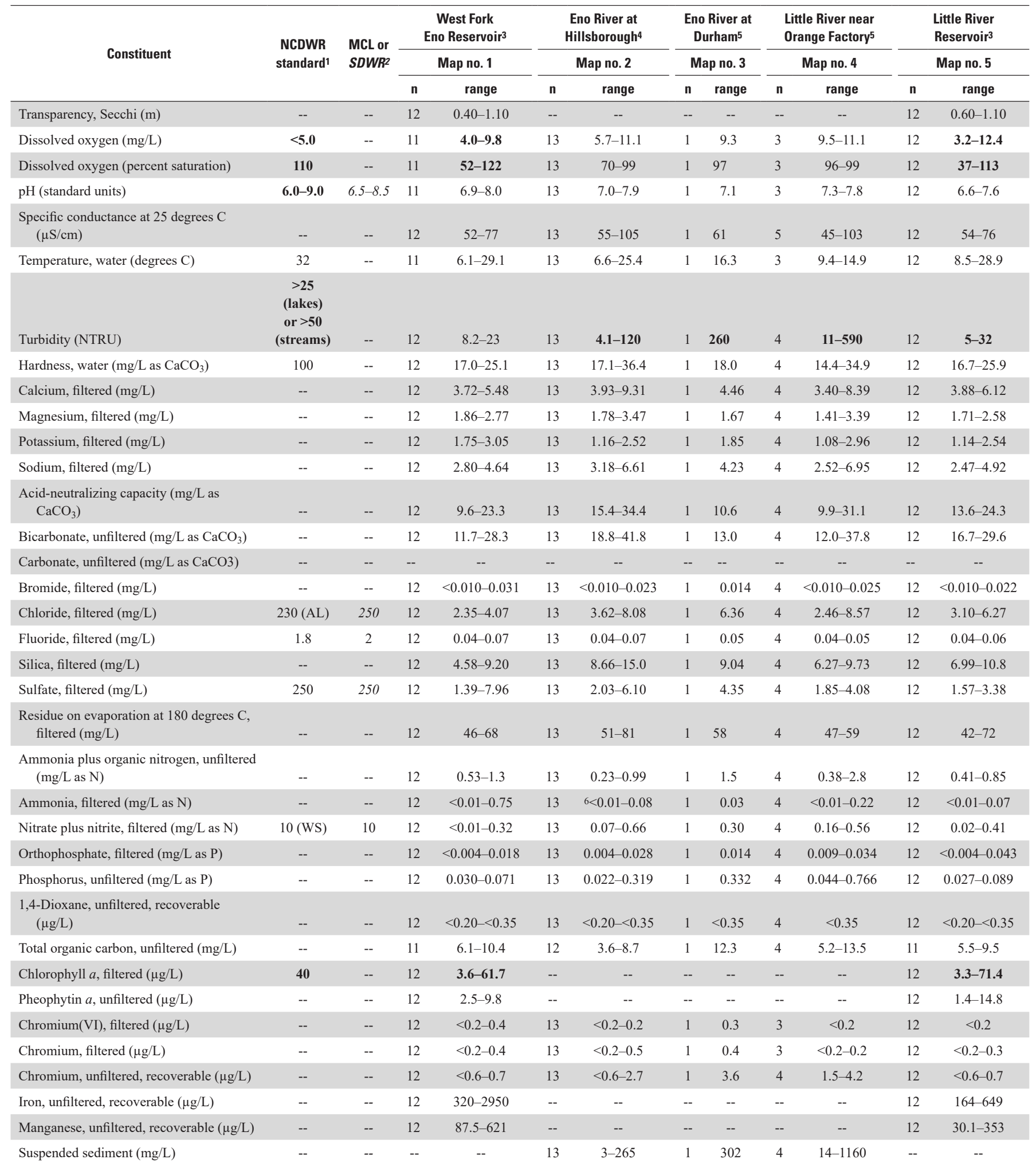


Table 4. Summary of water-quality results for sampled sites in the Triangle Area Water Supply Monitoring Project, October 2017-September 2019.-Continued

[Number under site name refers to the map number shown in figure 1 and table 1. NCDWR, North Carolina Division of Water Resources; MCL, maximum contaminant level; SDWR, secondary drinking water regulation; n, number of observations; range, minimum and maximum values; --, not available or constituent not sampled; m, meter; $\mathrm{mg} / \mathrm{L}$, milligram per liter; >, greater than; <, less than; $\mu \mathrm{S} / \mathrm{cm}$, microsiemens per centimeter; C, Celsius; NTRU, nephelometric turbidity ratio units; $\mathrm{CaCO}_{3}$, calcium carbonate; N, nitrogen; P, phosphorus; $\mu \mathrm{g} / \mathrm{L}$, microgram per liter; WS, water supply; exceedances of the NCDWR water-quality criterion are shown in bold. See footnotes at end of table]

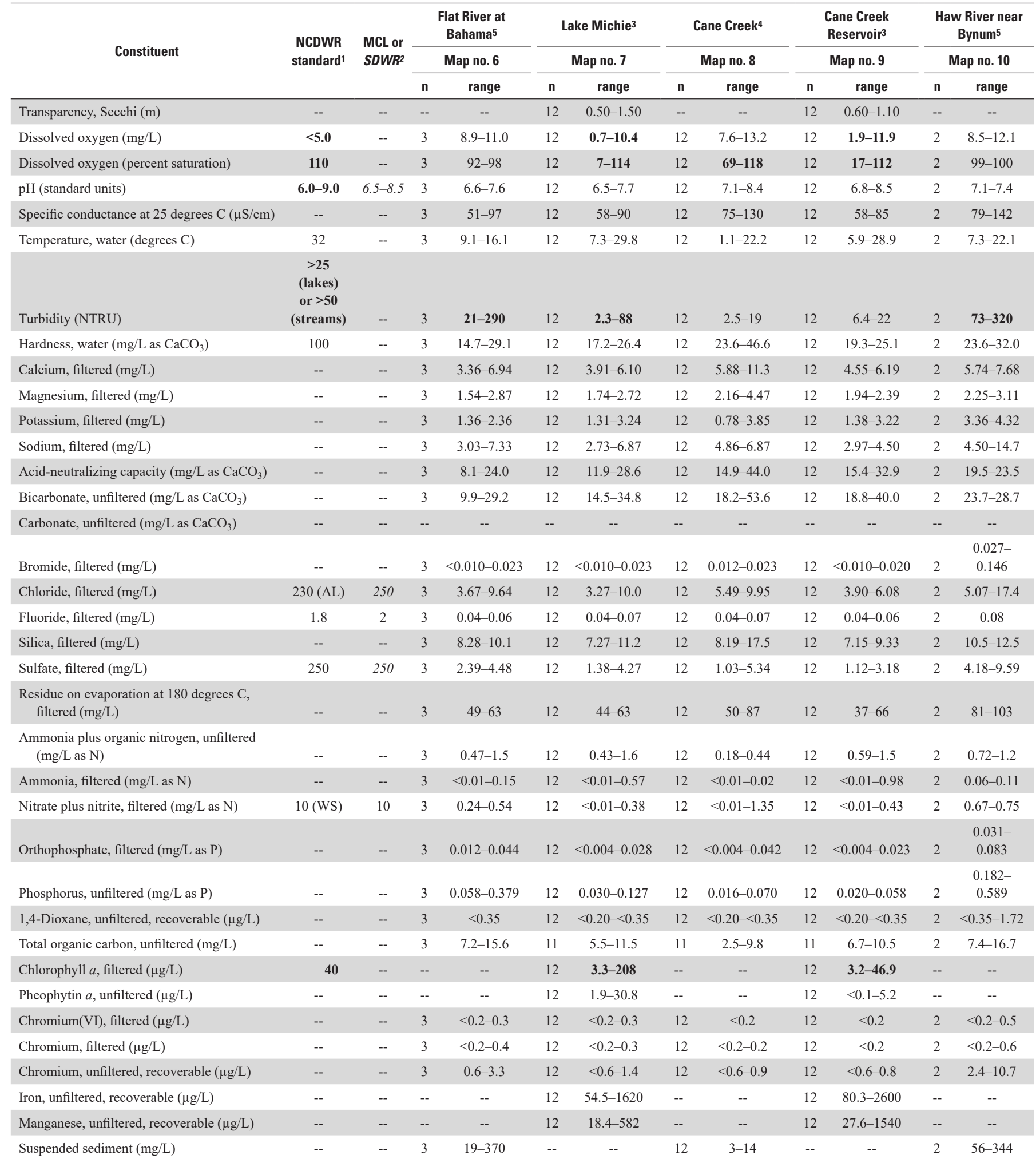


Table 4. Summary of water-quality results for sampled sites in the Triangle Area Water Supply Monitoring Project, October 2017September 2019.-Continued

[Number under site name refers to the map number shown in figure 1 and table 1. NCDWR, North Carolina Division of Water Resources; MCL, maximum contaminant level; SDWR, secondary drinking water regulation; $n$, number of observations; range, minimum and maximum values; --, not available or constituent not sampled; m, meter; mg/L, milligram per liter; >, greater than; <, less than; $\mu \mathrm{S} / \mathrm{cm}$, microsiemens per centimeter; C, Celsius; NTRU, nephelometric turbidity ratio units; $\mathrm{CaCO}_{3}$, calcium carbonate; $\mathrm{N}$, nitrogen; $\mathrm{P}$, phosphorus; $\mu \mathrm{g} / \mathrm{L}$, microgram per liter; WS, water supply; exceedances of the NCDWR water-quality criterion are shown in bold. See footnotes at end of table]

\begin{tabular}{|c|c|c|c|c|c|c|c|c|c|c|c|c|}
\hline \multirow{3}{*}{ Constituent } & \multirow{3}{*}{$\begin{array}{l}\text { NCDWR } \\
\text { standard1 }\end{array}$} & \multirow{3}{*}{$\begin{array}{l}\text { MCL or } \\
\text { SDWR2 }\end{array}$} & \multirow{2}{*}{\multicolumn{2}{|c|}{$\begin{array}{c}\begin{array}{c}\text { Jordan Lake, Haw } \\
\text { River arm }\end{array} \\
\text { Map no. } 11\end{array}$}} & \multirow{2}{*}{\multicolumn{2}{|c|}{$\begin{array}{c}\begin{array}{c}\text { New Hope } \\
\text { Creek }^{5}\end{array} \\
\text { Map no. } 12\end{array}$}} & \multirow{2}{*}{\multicolumn{2}{|c|}{$\begin{array}{c}\text { Northeast Creek } \\
\text { Map no. } 13\end{array}$}} & \multirow{2}{*}{\multicolumn{2}{|c|}{$\begin{array}{c}\begin{array}{c}\text { Morgan Creek } \\
\text { near White Cross }\end{array} \\
\text { Map no. } 14\end{array}$}} & \multirow{2}{*}{\multicolumn{2}{|c|}{$\begin{array}{c}\text { University Lake³ } \\
\text { Map no. } 15\end{array}$}} \\
\hline & & & & & & & & & & & & \\
\hline & & & $\mathbf{n}$ & range & & range & $\mathbf{n}$ & range & $\mathbf{n}$ & range & $\mathbf{n}$ & range \\
\hline Transparency, Secchi (m) & -- & -- & 12 & $0.40-1.10$ & -- & -- & -- & -- & -- & -- & 12 & $0.30-0.90$ \\
\hline Dissolved oxygen (mg/L) & $<5.0$ & -- & 12 & $7.4-12.7$ & 1 & 6.1 & 2 & $5.7-5.9$ & 12 & $6.5-13.4$ & 12 & $4.4-11.7$ \\
\hline Dissolved oxygen (percent saturation) & 110 & -- & 12 & 89-172 & 1 & 73 & 2 & $60-71$ & 12 & $76-129$ & 12 & 48-127 \\
\hline pH (standard units) & $6.0-9.0$ & $6.5-8.5$ & 12 & $6.8-9.2$ & 1 & 7.3 & 2 & $6.4-7.0$ & 12 & $7.1-8.7$ & 12 & $6.7-8.2$ \\
\hline $\begin{array}{l}\text { Specific conductance at } 25 \text { degrees } \mathrm{C} \\
(\mu \mathrm{S} / \mathrm{cm})\end{array}$ & -- & -- & 12 & $86-409$ & 1 & 93 & 2 & $72-80$ & 12 & 88-184 & 12 & $76-127$ \\
\hline Temperature, water (degrees C) & 32 & -- & 12 & $6.6-30.9$ & 1 & 23.9 & 2 & $17.1-23.8$ & 12 & $1.4-22.6$ & 12 & $6.7-30.1$ \\
\hline Turbidity (NTRU) & $\begin{array}{c}>\mathbf{2 5} \\
\text { (lakes) } \\
\text { or }>\mathbf{5 0} \\
\text { (streams) }\end{array}$ & -- & 12 & $7.2-33$ & 1 & 160 & 2 & 96-270 & 12 & $0.6-20$ & 12 & $7.8-40$ \\
\hline Hardness, water $\left(\mathrm{mg} / \mathrm{L}\right.$ as $\left.\mathrm{CaCO}_{3}\right)$ & 100 & -- & 12 & $24.9-51.0$ & 1 & 23.2 & 2 & $18.5-21.1$ & 12 & $27.6-53.7$ & 12 & $22.9-42.1$ \\
\hline Calcium, filtered $(\mathrm{mg} / \mathrm{L})$ & -- & -- & 12 & $5.93-13.3$ & 1 & 6.38 & 2 & $4.81-5.60$ & 12 & $6.66-13.6$ & 12 & $5.78-11.4$ \\
\hline Magnesium, filtered (mg/L) & -- & -- & 12 & $2.45-4.32$ & 1 & 1.77 & 2 & $1.57-1.73$ & 12 & $2.52-4.81$ & 12 & $2.06-3.30$ \\
\hline Potassium, filtered $(\mathrm{mg} / \mathrm{L})$ & -- & -- & 12 & $2.31-7.38$ & 1 & 2.94 & 2 & $2.40-2.57$ & 12 & $0.98-7.21$ & 12 & $1.27-2.95$ \\
\hline Sodium, filtered (mg/L) & -- & -- & 12 & $6.07-56.5$ & 1 & 7.61 & 2 & $6.26-7.08$ & 12 & $5.32-10.3$ & 12 & $4.68-7.55$ \\
\hline $\begin{array}{l}\text { Acid-neutralizing capacity ( } \mathrm{mg} / \mathrm{L} \text { as } \\
\mathrm{CaCO}_{3} \text { ) }\end{array}$ & -- & -- & 12 & $19.0-59.4$ & 1 & 21.2 & 2 & $14.9-20.5$ & 12 & $21.0-56.5$ & 12 & $15.9-38.2$ \\
\hline Bicarbonate, unfiltered $\left(\mathrm{mg} / \mathrm{L}\right.$ as $\left.\mathrm{CaCO}_{3}\right)$ & -- & -- & 12 & $23.1-71.1$ & 1 & 25.9 & 2 & $18.2-25.0$ & 12 & $25.6-68.7$ & 12 & $19.4-46.5$ \\
\hline Carbonate, unfiltered $\left(\mathrm{mg} / \mathrm{L}\right.$ as $\left.\mathrm{CaCO}_{3}\right)$ & -- & -- & 1 & 3.8 & -- & -- & -- & -- & -- & -- & 1 & 0.5 \\
\hline Bromide, filtered $(\mathrm{mg} / \mathrm{L})$ & -- & -- & 12 & $0.025-1.19$ & 1 & 0.020 & 2 & $0.018-0.023$ & 12 & $0.011-0.025$ & 12 & $0.013-0.029$ \\
\hline Chloride, filtered $(\mathrm{mg} / \mathrm{L})$ & $230(\mathrm{AL})$ & 250 & 12 & $6.99-50.3$ & 1 & 6.44 & 2 & $5.58-6.82$ & 12 & $5.75-13.2$ & 12 & $4.82-9.13$ \\
\hline Fluoride, filtered $(\mathrm{mg} / \mathrm{L})$ & 1.8 & 2 & 12 & $0.06-0.27$ & 1 & 0.07 & 2 & $0.07-0.08$ & 12 & $0.03-0.07$ & 12 & $0.04-0.07$ \\
\hline Silica, filtered $(\mathrm{mg} / \mathrm{L})$ & -- & -- & 12 & $2.18-13.7$ & 1 & 6.30 & 2 & $5.95-8.37$ & 12 & $8.49-16.7$ & 12 & $11.0-16.4$ \\
\hline Sulfate, filtered $(\mathrm{mg} / \mathrm{L})$ & 250 & 250 & 12 & $5.6-35.7$ & 1 & 6.48 & 2 & $3.55-3.93$ & 12 & $2.40-6.36$ & 12 & $2.79-11.1$ \\
\hline $\begin{array}{l}\text { Residue on evaporation at } 180 \text { degrees } \mathrm{C} \text {, } \\
\text { filtered }(\mathrm{mg} / \mathrm{L})\end{array}$ & -- & -- & 12 & $63-248$ & 1 & 68 & 2 & $47-83$ & 12 & $66-116$ & 12 & $62-82$ \\
\hline $\begin{array}{l}\text { Ammonia plus organic nitrogen, unfiltered } \\
(\mathrm{mg} / \mathrm{L} \text { as } \mathrm{N})\end{array}$ & -- & -- & 12 & $0.38-1.2$ & 1 & 0.82 & 2 & $0.73-0.88$ & 12 & $0.13-2.6$ & 12 & $0.41-1.3$ \\
\hline Ammonia, filtered (mg/L as N) & -- & -- & 12 & $<0.01-0.09$ & 1 & $<0.01$ & 2 & $<0.01-0.02$ & 12 & $<0.01-1.39$ & 12 & $<0.01-0.65$ \\
\hline Nitrate plus nitrite, filtered ( $\mathrm{mg} / \mathrm{L}$ as $\mathrm{N}$ ) & 10 (WS) & 10 & 12 & $0.05-1.16$ & 1 & 0.59 & 2 & $0.12-0.17$ & 12 & $<0.01-1.39$ & 12 & $7<0.01-0.37$ \\
\hline Orthophosphate, filtered (mg/L as $\mathrm{P}$ ) & -- & -- & 12 & $<0.004-0.042$ & 1 & 0.048 & 2 & $0.019-0.045$ & 12 & $0.004-0.167$ & 12 & $<0.004-0.010$ \\
\hline Phosphorus, unfiltered (mg/L as $\mathrm{P}$ ) & -- & -- & 12 & $0.036-0.143$ & 1 & 0.223 & 2 & $0.163-0.239$ & 12 & $0.008-0.298$ & 12 & $0.031-0.117$ \\
\hline $\begin{array}{l}\text { 1,4-Dioxane, unfiltered, recoverable } \\
(\mu \mathrm{g} / \mathrm{L})\end{array}$ & -- & -- & 12 & $<0.35-25.8$ & 1 & $<0.35$ & 2 & $<0.35$ & 12 & $<0.20-<0.35$ & 12 & $<0.20-<0.35$ \\
\hline Total organic carbon, unfiltered (mg/L) & -- & -- & 12 & $4.0-10.3$ & 1 & 11.4 & 2 & $15.8-17.7$ & 11 & $2.1-9.0$ & 11 & $84.2-10.5$ \\
\hline Chlorophyll $a$, filtered $(\mu \mathrm{g} / \mathrm{L})$ & 40 & -- & 12 & $2.7-62.2$ & -- & -- & -- & -- & -- & -- & 12 & $17.1-59.6$ \\
\hline Pheophytin $a$, unfiltered $(\mu \mathrm{g} / \mathrm{L})$ & -- & -- & 12 & $1.5-13.4$ & -- & -- & -- & -- & -- & -- & 12 & $3.6-12.8$ \\
\hline Chromium(VI), filtered ( $\mu \mathrm{g} / \mathrm{L}$ ) & -- & -- & 12 & $<0.2-0.4$ & 1 & 0.3 & 2 & $0.3-0.4$ & 12 & $<0.2-0.6$ & 12 & $<0.2$ \\
\hline Chromium, filtered $(\mu \mathrm{g} / \mathrm{L})$ & -- & -- & 12 & $<0.2-0.5$ & 1 & 0.3 & 2 & 0.5 & 12 & $<0.2-0.5$ & 12 & $<0.2$ \\
\hline Chromium, unfiltered, recoverable $(\mu \mathrm{g} / \mathrm{L})$ & -- & -- & 12 & $<0.6-1.7$ & 1 & 3.3 & 2 & $<1.0-5.8$ & 12 & $<0.6-0.9$ & 12 & $<0.6-<1.0$ \\
\hline Iron, unfiltered, recoverable $(\mu \mathrm{g} / \mathrm{L})$ & -- & -- & 12 & 197-1090 & -- & -- & -- & -- & -- & -- & 12 & $185-1210$ \\
\hline Manganese, unfiltered, recoverable $(\mu \mathrm{g} / \mathrm{L})$ & -- & -- & 12 & $28.6-145$ & -- & -- & -- & -- & -- & -- & 12 & $60.5-272$ \\
\hline Suspended sediment $(\mathrm{mg} / \mathrm{L})$ & -- & -- & -- & -- & 1 & 137 & 2 & $58-136$ & 12 & $<0.5-17$ & -- & -- \\
\hline
\end{tabular}


Table 4. Summary of water-quality results for sampled sites in the Triangle Area Water Supply Monitoring Project, October 2017-September 2019.-Continued

[Number under site name refers to the map number shown in figure 1 and table 1. NCDWR, North Carolina Division of Water Resources; MCL, maximum contaminant level; SDWR, secondary drinking water regulation; n, number of observations; range, minimum and maximum values; --, not available or constituent not sampled; m, meter; mg/L, milligram per liter; >, greater than; <, less than; $\mu \mathrm{S} / \mathrm{cm}$, microsiemens per centimeter; C, Celsius; NTRU, nephelometric turbidity ratio units; $\mathrm{CaCO}_{3}$, calcium carbonate; $\mathrm{N}$, nitrogen; P, phosphorus; $\mu \mathrm{g} / \mathrm{L}$, microgram per liter; WS, water supply; exceedances of the NCDWR water-quality criterion are shown in bold. See footnotes at end of table]

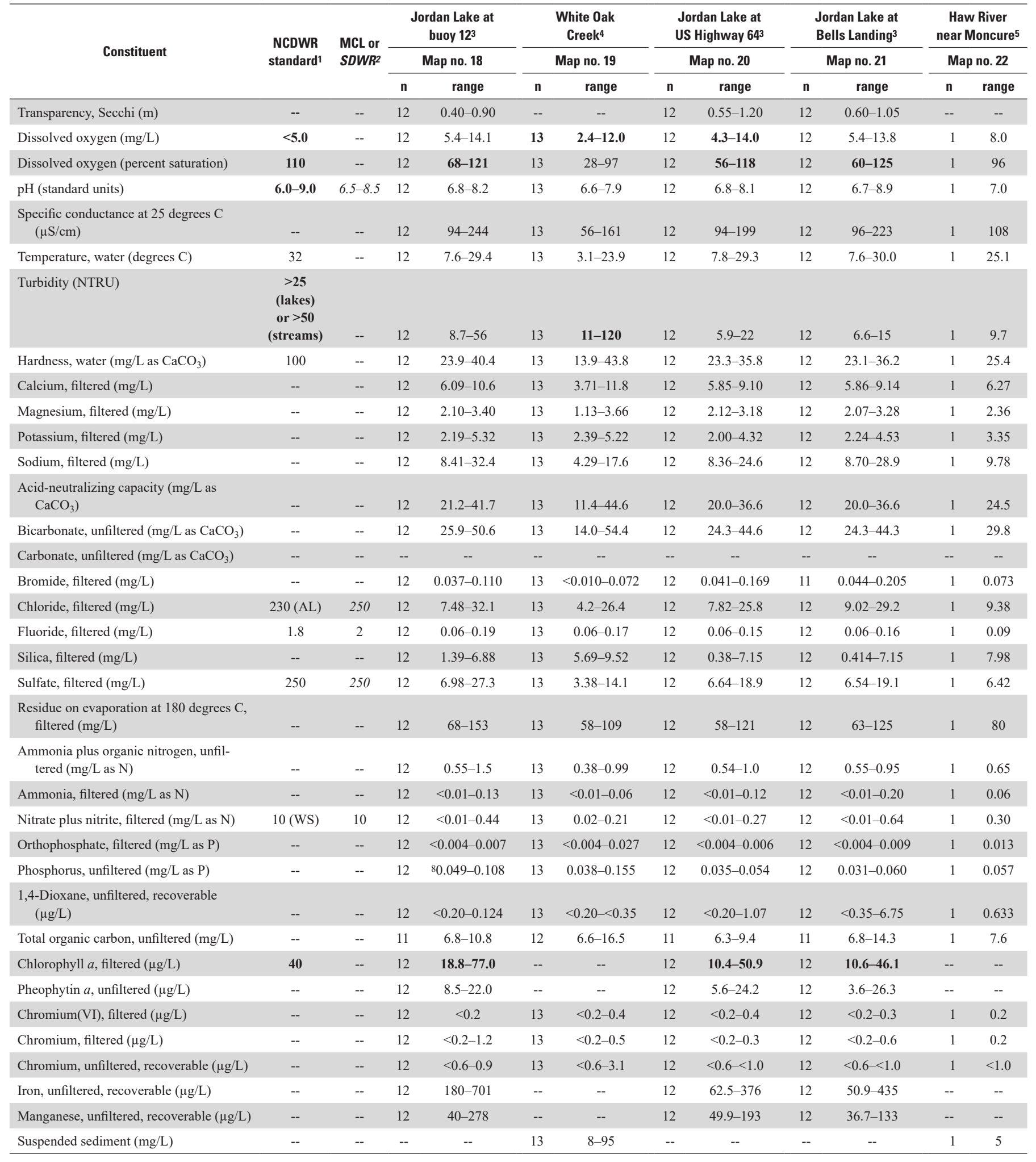


Table 4. Summary of water-quality results for sampled sites in the Triangle Area Water Supply Monitoring Project, October 2017-September 2019.-Continued

[Number under site name refers to the map number shown in figure 1 and table 1. NCDWR, North Carolina Division of Water Resources; MCL, maximum contaminant level; SDWR, secondary drinking water regulation; n, number of observations; range, minimum and maximum values; --, not available or constituent not sampled; m, meter; mg/L, milligram per liter; >, greater than; <, less than; $\mu \mathrm{S} / \mathrm{cm}$, microsiemens per centimeter; C, Celsius; NTRU, nephelometric turbidity ratio units; $\mathrm{CaCO}_{3}$, calcium carbonate; N, nitrogen; P, phosphorus; $\mu \mathrm{g} / \mathrm{L}$, microgram per liter; WS, water supply; exceedances of the NCDWR water-quality criterion are shown in bold.]

${ }^{1}$ NCDWR criteria listed (in the North Carolina surface water standards tables) are the most stringent for freshwater aquatic life, water supply (WS), or human health standards; $\mathrm{N}=$ narrative standard; $\mathrm{AL}=$ Action Level for freshwater aquatic life; dissolved oxygen percent saturation is evaluated relative to the total dissolved gases standard (North Carolina Department of Environmental Quality, 2020).

${ }^{2}$ MCLs for drinking water are listed if available; SDWRs are listed in italics if MCLs are not available (U.S. Environmental Protection Agency, 2020).

${ }^{3}$ Lake sites were sampled six times during each year on a fixed schedule.

${ }^{4}$ Stream sites were sampled six times during each year on a fixed schedule and may include additional storm-runoff sampling.

${ }^{5}$ Stream sites for supplemental storm-runoff sampling were sampled only during selected runoff events.

${ }^{6}$ The maximum value may be biased high because the analyte was detected at $0.012 \mathrm{mg} / \mathrm{L}$ in the laboratory blank during sample analysis.

7The maximum value might be affected by holding-time violation.

${ }^{8}$ The minimum value might be affected by holding-time violation. 

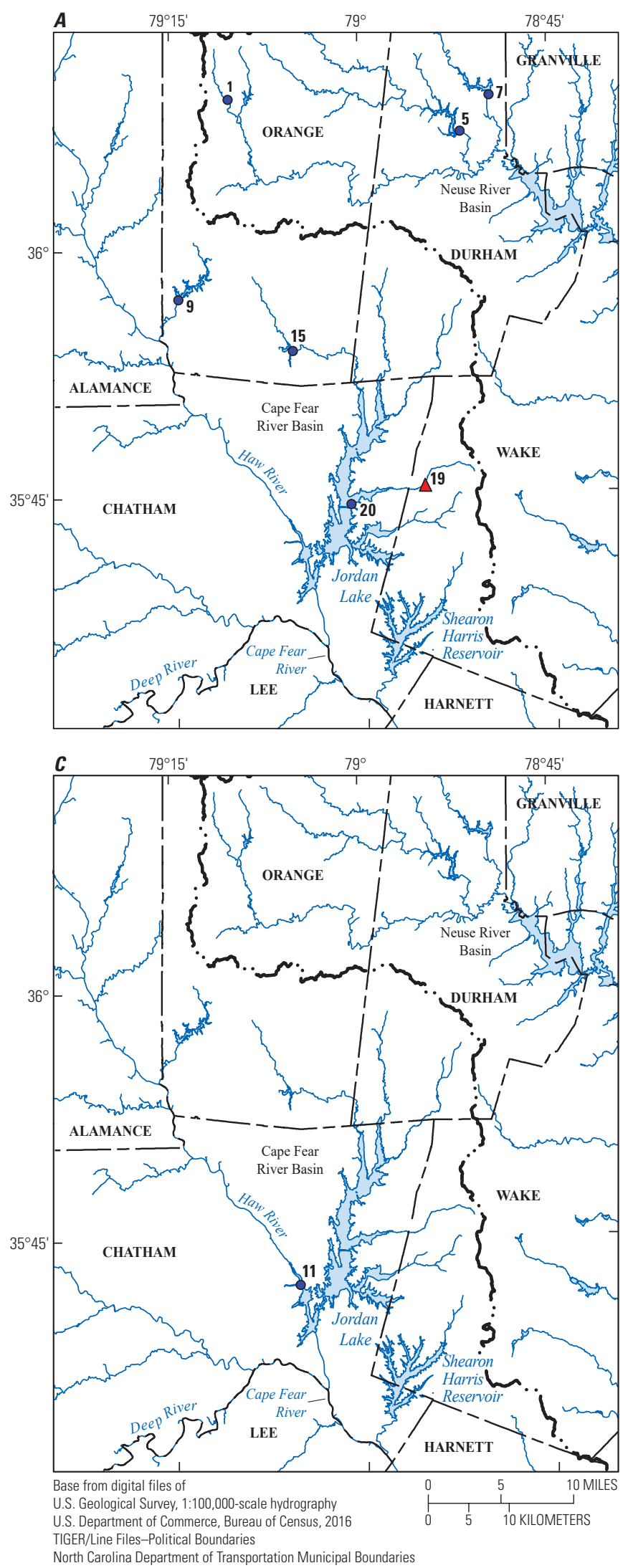
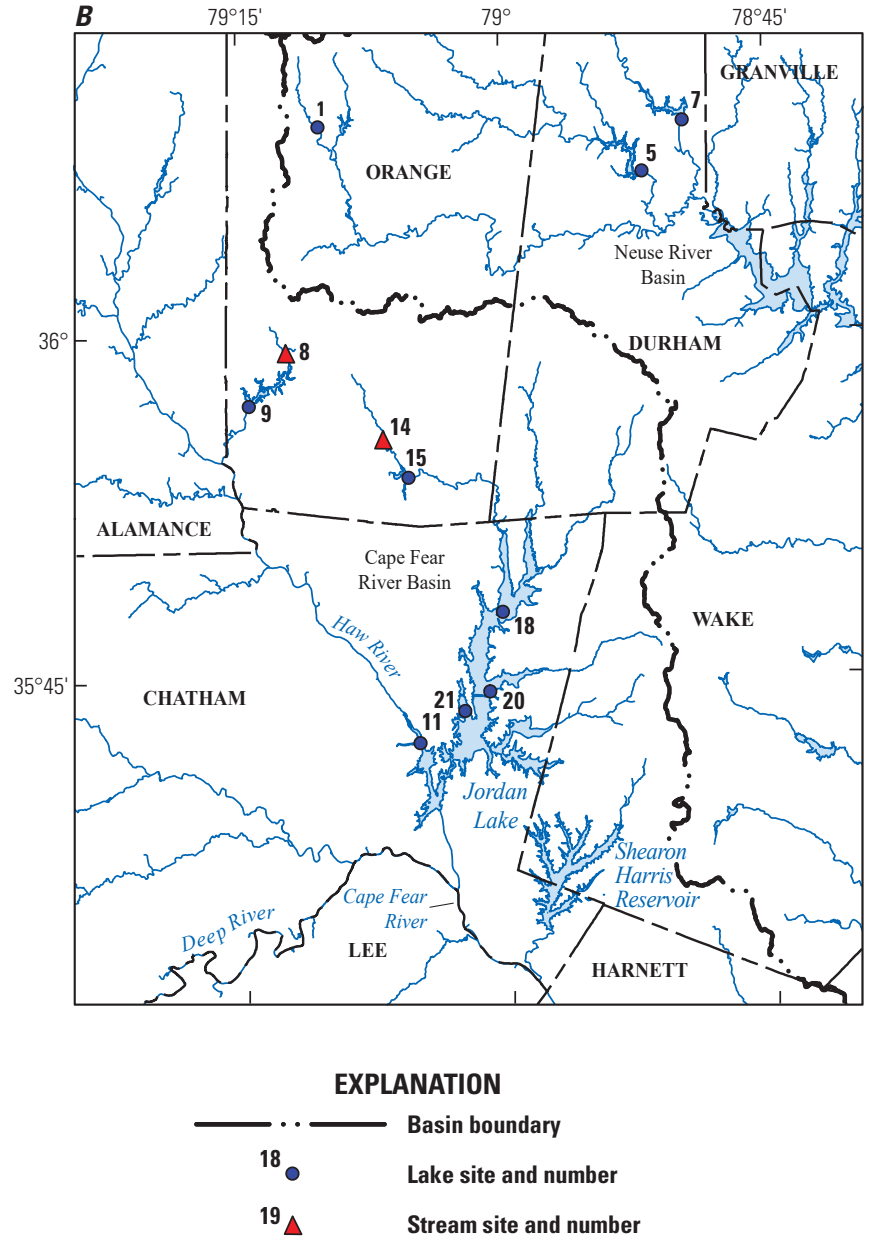

Figure 3. Maps showing sites in the Triangle area of North Carolina with one or more measurements of (A) dissolved-oxygen concentration $<5$ milligrams per liter, $(B)$ dissolved-oxygen percent saturation values $>110$ percent, (C) $\mathrm{pH}$ values $>9$ standard units, $(D)$ turbidity values $>25$ nephelometric turbidity ratio units for lakes and reservoirs or $>50$ nephelometric turbidity ratio units for streams, and (E) concentrations of chlorophyll a $>40$ micrograms per liter, October 2017-September 2019. Site information is provided in table 1. 


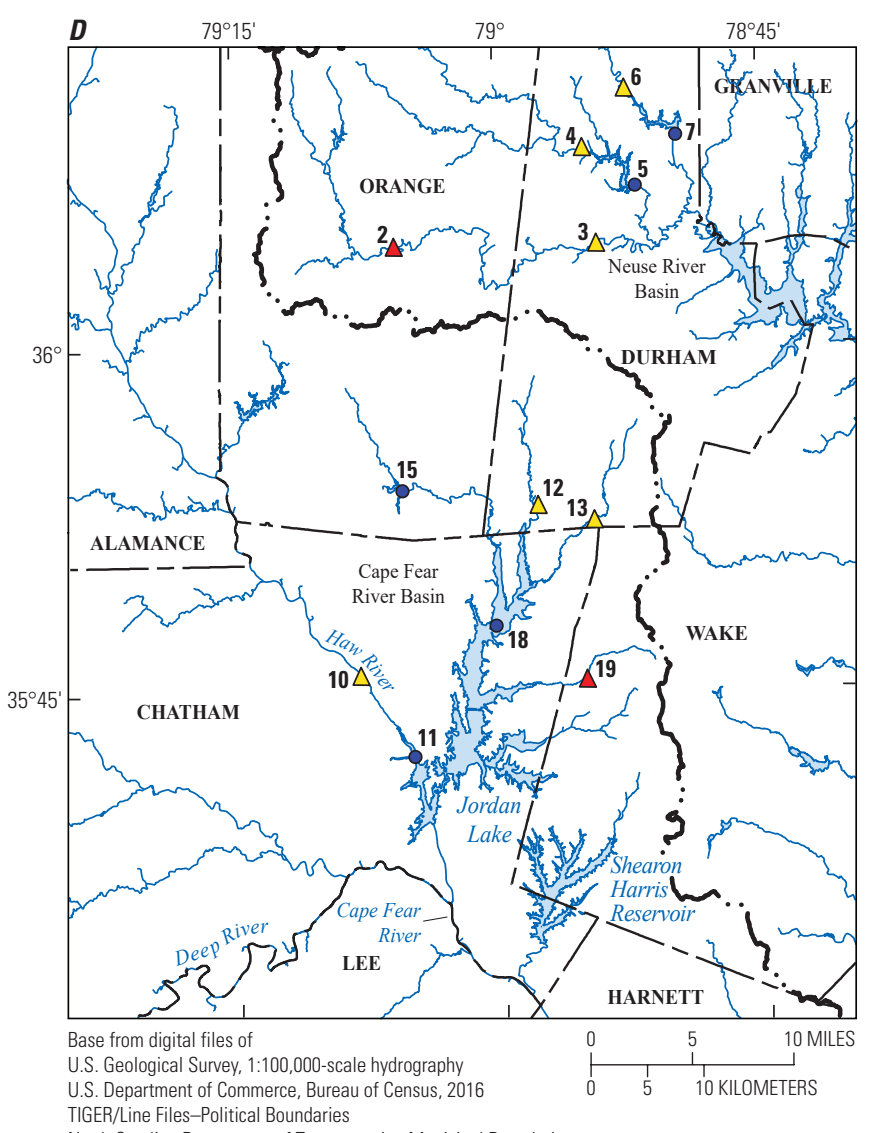

TIGER/Line Files-Political Boundaries

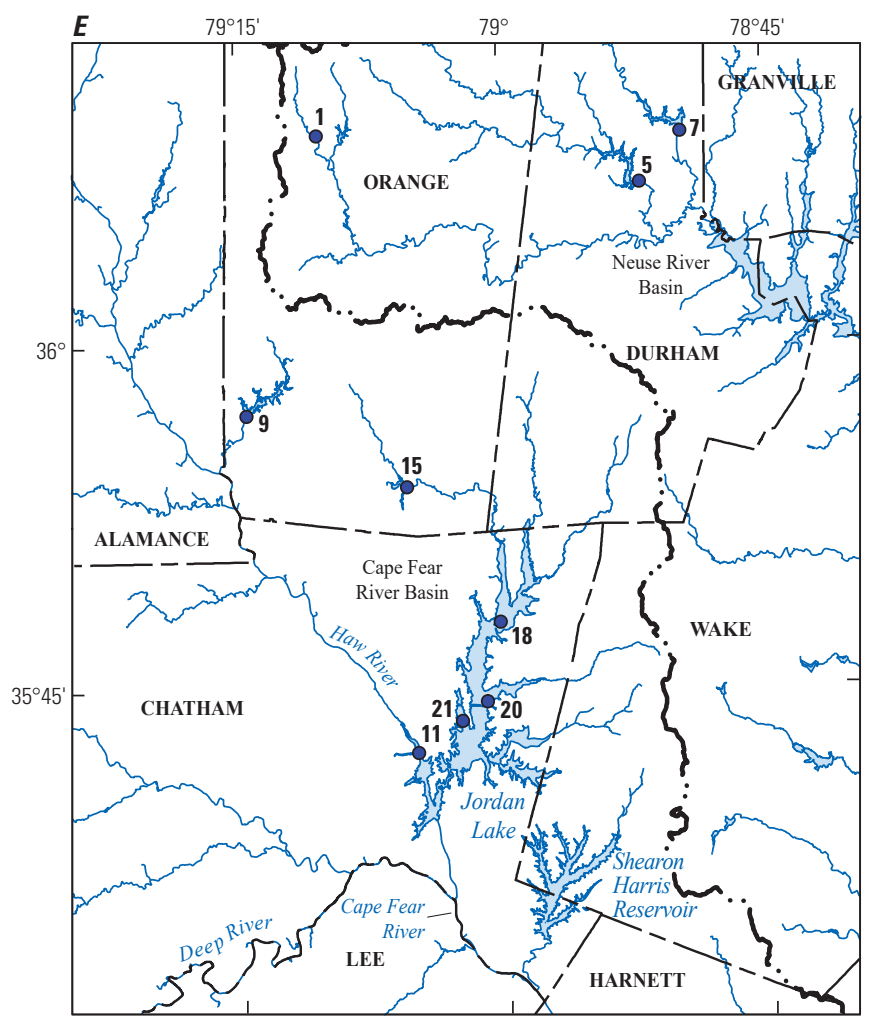

North Carolina Department of Transportation Municipal Boundaries

EXPLANATION

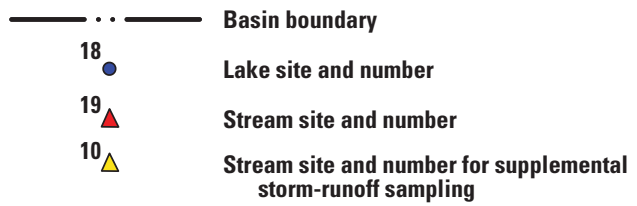

Figure 3.-Continued

\section{Summary}

From October 2017 through September 2019, more than 7,500 individual water-quality measurements were made at 20 sites, and continuous records of streamflow were collected at 10 streamflow-gaging stations in the Triangle Area Water Supply Monitoring Network. The project data-quality objectives were primarily met by obtaining and reviewing blank and replicate samples. Most of the blank detections were infrequent, and their concentrations were at or near the censoring levels. Two constituents - ammonia and suspended sediment - were detected frequently in sample blanks and at concentrations that could lead to a positive bias in a subset of the environmental samples. The replicate pairs indicated acceptable reproducibility for the water-quality constituents measured during water years 2018 and 2019 except for ammonia plus organic nitrogen and suspended sediment, in some cases. The USGS continues to monitor these two constituents to determine measures that can be taken to reduce the uncertainty of results from subsequent environmental samples.

Streamflow was below the long-term mean during water year 2018 at all sites except for Northeast Creek near Genlee (site 13), Morgan Creek near White Cross (site 14), Morgan Creek near Chapel Hill (site 16), and White Oak Creek (site 19). During water year 2019, streamflow was above the long-term mean at all ten sites. State water-quality thresholds are available for 11 of the 36 constituents measured. These thresholds were exceeded one or more times for dissolved oxygen (14 samples, 6 lake sites, 1 stream site), dissolvedoxygen percent saturation ( 21 samples, 9 lake sites, 2 stream sites), $\mathrm{pH}$ (1 sample, 1 lake site), turbidity (22 samples, 5 lake sites, 8 stream sites), and chlorophyll $a$ (22 samples, 9 lake sites). No samples exceeded thresholds for water temperature, hardness, chloride, fluoride, sulfate, and nitrate plus nitrite. 


\section{References Cited}

Anderson, C.W., 2005, Turbidity (ver. 2.1, September 2005): U.S. Geological Survey Techniques of Water-Resources Investigations, book 9, chap. A6.7, 55 p., accessed June 26, 2020, at https://doi.org/10.3133/twri09A6.7.

ASTM International, 2002, ASTM standard D3977-97, Standard test methods for determining sediment concentration in water samples (2002 ed.): ASTM Compass website, 6 p., accessed January 15, 2021, at https://compass. astm.org/Standards/HISTORICAL/D3977-97R02.htm.

Arar, E.J., and Collins, G.B., 1997, Method 445.0-In vitro determination of chlorophyll a and pheophytin a in marine and freshwater algae by fluorescence (rev. 1.2): Cincinnati, Ohio, U.S. Environmental Protection Agency, 21 p., accessed August 6, 2018, at https://cfpub.epa.gov/si/si public_record_report.cfm?Lab $=$ NERL\&dirEntryId=309417.

Ball, J.W., and McCleskey, R.B., 2003, A new cationexchange method for accurate field speciation of hexavalent chromium: U.S. Geological Survey Water-Resources Investigations Report 03-4018, 17 p., accessed June 26, 2020, at https://doi.org/10.3133/wri034018.

Cain, J.L., Pfeifle, C.A., and Rasmussen, R.B., 2020, Associated data for the Triangle Area Water Supply Monitoring Project, North Carolina, October 2017September 2019: U.S. Geological Survey data release, https://doi.org/10.5066/P9KQ6KH2.

Clesceri, L.S., Greenberg, A.E., and Eaton, A.D., eds., 1998a, High temperature combustion, pt. 5310B of Standard methods for the examination of water and wastewater (20th ed.): Washington, D.C., American Public Health Association, American Water Works Association, and Water Environment Federation, p. 5-20-5-21.

Clesceri, L.S., Greenberg, A.E., and Eaton, A.D., eds., 1998b, Metals plasma emission spectroscopy, pt. 3120 of Standard methods for the examination of water and wastewater (20th ed.): Washington, D.C., American Public Health Association, American Water Works Association, and Water Environment Federation, p. 3-37-3-43.

Fishman, M.J., ed., 1993, v. 93-125. Methods of analysis by the U.S. Geological Survey National Water Quality Laboratory-Determination of inorganic and organic constituents in water and fluvial sediments, U.S. Geological Survey Open-File Report, 217 p. [Also available at https://doi.org/10.3133/ofr93125.].

Fishman, M.J., and Friedman, L.C., eds., 1989, Methods for determination of inorganic substances in water and fluvial sediments ( $3 d$ ed.): U.S. Geological Survey Techniques of Water-Resources Investigations, book 5, chap. A1, 545 p. [Also available at https://doi.org/10.3133/twri05A1.]
Garbarino, J.R., and Struzeski, T.M., 1998, Methods of analysis by the U.S. Geological Survey National Water Quality Laboratory-Determination of elements in whole-water digests using inductively coupled plasma-optical emission spectrometry and inductively coupled plasma-mass spectrometry: U.S. Geological Survey Open-File Report 98-165, 101 p. [Also available at https://doi.org/10.3133/ofr98165.]

Hambrook Berkman, J.A., and Canova, M.G., 2007, Algal biomass indicators (ver. 1.0, August 2007): U.S. Geological Survey Techniques of Water-Resources Investigations, book 9, chap. A7.4, 82 p., accessed June 28, 2018, at https://doi.org/10.3133/twri09A7.4.

North Carolina Department of Environmental Quality, 2020, Surface water standards-NC surface water quality standards tables (updated June 10, 2019): North Carolina Department of Environmental Quality website, accessed May 13, 2020, at https://deq.nc.gov/about/divisions/waterresources/planning/classification-standards/surface-waterstandards\#WQSTables.

Oblinger, C.J., 2004, Triangle Area Supply Monitoring Project, October 1988 through September 2001, North Carolina-Description of the water-quality network, sampling and analysis methods, and quality-assurance practices: U.S. Geological Survey Open-File Report 2004-1278, 56 p. [Also available at https://doi.org/10.3133/ ofr20041278.].

Patton, C.J., and Kryskalla, J.R., 2011, Colorimetric determination of nitrate plus nitrite in water by enzymatic reduction, automated discrete analyzer methods: U.S. Geological Survey Techniques and Methods, book 5, chap. B8, 34 p. [Also available at https://doi.org/10.3133/tm5B8.]

Patton, C.J., and Truitt, E.P., 2000, Methods of analysis by the U.S. Geological Survey National Water Quality Laboratory-Determination of ammonium plus organic nitrogen by a Kjeldahl digestion method and an automated photometric finish that includes digest cleanup by gas diffusion: U.S Geological Survey Open-File Report 00-170, $31 \mathrm{p}$. [Also available at https://doi.org/10.3133/ofr00170.]

Pfeifle, C.A., Cain, J.L., and Rasmussen, R.B., 2016, Quality of surface-water supplies in the Triangle area of North Carolina, water years 2010-11: U.S. Geological Survey Open-File Report 2016-1002, 19 p., https://doi.org/10.3133/ ofr20161002

Pfeifle, C.A., Cain, J.L., and Rasmussen, R.B., 2019, Triangle Area Water Supply Monitoring Project, North CarolinaSummary of monitoring activities, quality assurance, and data, October 2015-September 2017: U.S. Geological Survey Open-File Report 2019-1077, 16 p., https://doi.org/ 10.3133/ofr20191077. 
Radtke, D.B., Davis, J.V., and Wilde, F.D., 2005, Specific electrical conductance (ver. 1.2, August 2005): U.S. Geological Survey Techniques of Water-Resources Investigations, book 9, chap. A6.3, 20 p., accessed June 28, 2018, at https://doi.org/10.3133/tm9A6.3.

Ritz, G.F., and Collins, J.A., 2008, pH (ver. 2.0, October 2008): U.S. Geological Survey Techniques of Water-Resources Investigations, book 9, chap. A6.4, 28 p., accessed June 28, 2018, at https://doi.org/10.3133/twri09A6.4.

Rose, D.L., Sandstrom, M.W., and Murtagh, L.K., 2016, Determination of heat purgeable and ambient purgeable volatile organic compounds in water by gas chromatography/mass spectrometry: U.S. Geological Survey Techniques and Methods, book 5, chap. B12, 61 p., https://doi.org/10.3133/tm5B12.

Rounds, S.A., 2012, Alkalinity and acid neutralizing capacity (ver. 4.0, September 2012): U.S. Geological Survey Techniques of Water-Resources Investigations, book 9, chap. A6.6, 43 p., accessed June 28, 2018, at https://doi.org/10.3133/twri09A6.6.

Rounds, S.A., Wilde, F.D., and Ritz, G.F., 2013, Dissolved oxygen (ver. 3.0, September 2013): U.S. Geological Survey Techniques of Water-Resources Investigations, book 9, chap. A6.2, 55 p., accessed June 28, 2018, at https://doi.org/10.3133/tm9A6.2.

U.S. Environmental Protection Agency, 1993, Method 365.1Determination of phosphorus by semi-automated colorimetry (revision 2.0): Cincinnati, Ohio, U.S. Environmental Protection Agency, $16 \mathrm{p}$.
U.S. Environmental Protection Agency, 2020, Secondary drinking water standards-Guidance for nuisance chemicals web page: U.S. Environmental Protection Agency website, accessed May 13, 2020, at https://www.epa.gov/dws tandardsregulations/secondary-drinking-water-standardsguidance-nuisance-chemicals.

U.S. Geological Survey, 2020a, Annual water data reports web page: U.S. Geological Survey website, accessed February 20, 2020, at https://wdr.water.usgs.gov/.

U.S. Geological Survey, 2020b, USGS water data for the Nation: U.S. Geological Survey National Water Information System database, accessed February 20, 2020, at https://doi.org/10.5066/F7P55KJN.

U.S. Geological Survey, [variously dated], National field manual for the collection of water quality data, section A of Handbooks for water-resources investigations: U.S. Geological Survey Techniques of Water-Resources Investigations, book 9, 10 chap. (A0-A8, A10), accessed September 2, 2020, at https://pubs.water.usgs.gov/twri9A.

Wilde, F.D., 2006, Temperature (ver. 2.0, March 2006): U.S. Geological Survey Techniques of Water-Resources Investigations, book 9, chap. A6.1, 20 p., accessed June 28, 2018, at https://doi.org/10.3133/twri09A6.1. 

For more information about this publication, contact:

Director, South Atlantic Water Science Center U.S. Geological Survey

1770 Corporate Drive

Suite 500

Norcross, GA 30093

Find additional information at https://www.usgs.gov/centers/sa-water 


\section{$\frac{\mathbb{2}}{50}$}

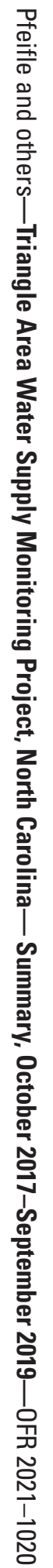

